\title{
THE POLITICAL ASPECTS OF JUDIGIAL POWER: SOME NOTES ON THE PRESIDENTIAL IMMUNITY DEGISION
}

\section{Stephen L. Carter $\uparrow$}

\section{INTRODUCTION}

We live in a society that chooses with increasing frequency to leave its most difficult questions for judicial resolution. Until recently, however, the problem of how to punish a miscreant who happens to reside in the White House had never been tossed into the courts. When the President went wrong, the political system dealt with him.

Presidents have gone wrong frequently. Presidents have been accused of misconduct in office for about as long as there have been Presidents. ${ }^{1}$ If the more recent Chief Executives sometimes seem to have been especially fond of abusing their powers, ${ }^{2}$ that may only be because historians, viewing the distant past through the glass of folklore, have been kind.

Rarely have formal punishments for presidential misconduct been meted out. Only one President has been impeached. None has ever been convicted. The process, moreover, has been decidedly political: The three Presidents who came closest to being formally removed from office-John Tyler, Andrew Johnson, and Richard Nixon-were extraordinarily unpopular by the time Congress began to act against them. In general, presidential abuse of authority has been punished, if at all, through legislative actions short of impeachment, through failure of reelection, or through trashing of the President's historical image. The federal courts have played only a limited role in keeping Presidents within the bounds of the law. When they have reviewed presidential actions, they have almost always done so indirectly through the fiction of a suit against the official charged with implementing the

$\dagger$ Assistant Professor of Law, Yale University. B.A. 1976, Stanford University; J.D. 1979, Yale University.

I am grateful to Enola Aird, Guido Calabresi, Robert Cover, Martha Minow, Peter Schuck, and Harry Wellington for their thoughtful and generous criticism on earlier versions of this essay. I have also benefitted from the efforts of Dean Hashimoto and Gerard Nolan, who referred me to a number of useful sources.

1 See generally Responses of the Presidents to Charges of Misconduct (C. Woodward ed. 1974).

2 See, e.g., A. Schlesinger, The Imperial Presidency (1973); Bernstein, The Road to Watergate and Beyond: The Growth and Abuse of Executive Authority Since 1940, LAW \& ConTemp. Probs., Spring 1976, at 58. 
disputed policy. ${ }^{3}$ Until just a few years ago, courts routinely dismissed actions naming the President as a defendant." The courts willingly sent signals to the other branches on the constitutionality of presidential acts, but they refused to proceed against the President directly.

So matters stood when, in the summer of 1974, a unanimous Supreme Court ruled in United States $v$. Nixon that, in appropriate circumstances, the President was a proper subject for judicial process. ${ }^{5}$ The Court found judicial process appropriate where the President had custody of tape recordings subpoenaed for use in a criminal case. By refusing to quash the subpoena, the Justices raised a fresh question, one that prior practice had avoided: What if the President refuses to comply? That question became moot; he did comply, leaving legal scholars to speculate on whether the federal courts could have held him in contempt if he had not.

This Article speculates that the contempt issue should be viewed as part of a larger question: Who has the authority to punish the President when he violates his oath? Punishment of the President, the Article suggests, is in essence a political task. The Article takes as its point of departure Nixon $v$. Fitzgerald, ${ }^{6}$ decided by the Court early in the summer of 1982. In Nixon $v$. Fitzgerald, the presidential immunity decision of this Article's title, a sharply divided Court ruled that an individual's suit for damages was not a circumstance in which subjecting the President to judicial process was appropriate. ${ }^{7}$ The message of that case may well be that had the President not turned over the tapes at issue in United States $v$. Nixon, the federal courts could have done

Through the years, many a landmark decision has been rendered in this manner. See, e.g., Marbury v. Madison, 5 U.S. (1 Cranch) 137 (1803) (suit against Secretary of State); Youngstown Sheet \& Tube Co. v. Sawyer, 343 U.S. 579 (1952) (The Steel Seizure Case) (suit against Secretary of Commerce); Dames \& Moore v. Regan, 453 U.S. 654 (1981) (The Iranian Assets Case) (suit against Secretary of Treasury). Before the Court's 1952 decision in Youngstown, presidential actions challenged in federal court through this subterfuge were invariably sustained. See Kauper, The Steel Seizure Case: Congress, the President and the Supreme Court, 51 Mrck. L. REv. 141, 144-51 (1952).

See, e.g., Mississippi v. Johnson, 71 U.S. (4 Wall.) 475 (1867); Livingston v. Jefferson, 15 F. Cas. 660 (C.C. Va. 1811) (No. 8411).

s 418 U.S. $683,705-07$ (1974).

- 457 U.S. 731 (1982). This point is as good as any for a confession and a disclaimer. The author first became interested in these issues while serving as a law clerk to Justice Marshall during the Term in which the first presidential immunity case, Kissinger v. Halperin, 452 U.S. 713 (1981), came before the Court. The judgment in that case was affirmed by an equally divided Court. The author had no part in any deliberations concerning the second presidential immunity case, Nixon $v$. Fitzgerald, which provides the springboard for analysis in this essay. Nixon v. Fitzgerald, was briefed, argued, and decided after the author completed his clerkship.

7 Nixon v. Fitzgerald, 457 U.S. at 748. 
nothing at all: the constitutional analysis in Nixon $v$. Fitzgerald leads almost ineluctably to the proposition that the judicial power of the United States does not include the authority to punish the President of the United States.

That conclusion is not indefensible, but in a society premised on the rule of law, it ought to be controversial. Early commentary on Nixon $v$. Fitzgerald focused on whether the case was rightly decided, ${ }^{8}$ rather than on the implications of the decision. Those implications, however, have both practical and theoretical significance, not because they spell doom for the republic, ${ }^{9}$ but because the reasoning and the result in the presidential immunity decision reflect a particular view of the judicial role in the system of checks and balances.

This view of the judiciary's role rests on something that those trained in the law do not always like to admit: the Constitution prescribes a system of government as well as of law, a political system as well as a legal one. The courts do not do everything that is necessary to govern the country, and when they act within the system of checks and balances, they are playing a political role. This system is dynamic and usually operates without judicially-enforceable rules. When the branches conflict, the winner will be not the one that cites the most cases but the one that can muster the most political support.

Judicial power to reach misconduct within the other branches of government thus has a political aspect. The power is exercised within a system of checks and balances, and the creation of any new remedy against one of the branches of government must affect the entire system. Nixon $v$. Fitzgerald suggests a judicial reluctance to create new remedies against the executive branch-even where needful to right a wrong-except in instances of the most compelling necessity. Demonstrating that the Fitzgerald result derives from the dual political and legal nature of the system requires that the Court's reasoning be re-

s See, e.g., Note, The Supreme Court, 1981 Term, 96 HARv. L. REv. 62, 226-36 (1982) (Nixon v. Fitzgerald result is departure from precedent); Flanz, The Constitution Does Not Grant Presidential Immunity, N.Y. Times, July 4, 1982, at E 14, col. 4 (letter to the editor) (no constitutional basis for the decision).

- After all, the United States has had Presidents for nearly two hundred years and none has ever been sued successfully for damages. That potential civil liability has been an important factor in presidential decisionmaking over the past two centuries is difficult to believe and impossible to prove. Moreover, the decisions that ultimately are the most important in the nation's history-whether to go to war, whom to nominate to the Supreme Court, how to structure a new regulatory initiative-would fall outside the reach of anyone's proposal for civil liability. Even Justice White's Nixon v. Fitzgerald dissent, which was joined by three other Justices, would apparently have granted absolute immunity for the performance of " $\mathrm{a}$ constitutionally assigned executive function, the performance of which would be substantially impaired by the possibility of a private action for damages." Nixon $v$. Fitzgerald, 457 U.S. at 785. 
viewed in some detail, dissected, and then reassembled in slightly different form. This analysis will make possible a consideration of what the case really says about the judicial role in checking and balancing the other branches of the federal government and what it implies for the relationship of the other two branches with one another.

\section{Dissecting the Presidential Immunity Decision}

\section{A. What the Court Said}

To understand what really happened in Nixon $v$. Fitzgerald, it is important to recall the context in which it arose. The plaintiff, a discharged civil servant, sued for damages based on causes of action that he claimed were properly to be implied from federal law and from the Constitution. ${ }^{10}$ These implied causes of action were the ones that the Supreme Court refused to recognize in a suit against the President of the United States even though the Court had recognized similar causes of action with respect to persons other than the President. That the rejected causes of action were "implied" matters because implied rights of action make little sense as anything except common law, which is to say law created by judges. ${ }^{11}$ Although the Supreme Court has tried various other explanations for what federal courts do when they imply a right to sue, ${ }^{12}$ a statute or clause not expressly providing a right to sue cannot reasonably be said to "create" one. Even if implying a private right of action is viewed as an exercise in statutory construction, it

10 The trial court held that Fitzgerald had stated causes of action under the first amendment, under 5 U.S.C. \$ 7211 (Supp. III 1979) (which grants executive employees the right to give congressional testimony), and under 18 U.S.C. $\S 1505$ (Supp. III 1979) (which makes obstruction of congressional testimony a crime). 457 U.S. at 740 $41 \&$ n.20. The majority stated that the implication issue was not before the Court, id., but as the text makes clear, that is arguably the very question the Court decided.

11 See generally P. Bator, P. Mishkin, D. Shapiro, \& H. Wechsler, Hart \& Wechsler's The Federal Courts and the Federal System 798-800 (2d ed. 1973); Monaghan, The Supreme Court, 1974 Term-Foreword: Constitutional Common Law, 89 HaRv. L. REv. 1 (1975); Note, Implied Causes of Action: A Product of Statutory Construction or the Federal Common Law Power?, 51 U. Colo. L. REv. 355 (1980).

${ }^{12}$ For instance, at one time the Court explained that, in implying a right to sue, it was applying the common-law statutory tort doctrine. See Texas \& Pac. Ry. v. Rigsby, 241 U.S. 33, 39-40 (1916). In the mid-1960's, the Court explained that it was merely applying those remedies "necessary to make effective the congressional purpose." J. I. Case Co. v. Borak, 377 U.S. 426, 433 (1964). More recently, the Court has promulgated a four-part "test" for implying private rights to sue. See Cort v. Ash, 422 U.S. 66,78 (1975). In the last several Terms, some of the Justices have suggested that the only proper question is whether Congress, at the time it enacted the legislation in question, actually "intended" to permit private suits. See Cannon v. University of Chicago, 441 U.S. 677, 717-18 (1979) (Rehnquist, J., concurring); id. at 718-30 (White, J., joined by Blackmun, J., dissenting); id. at 730-49 (Powell, J., dissenting). 
is the judge who performs the delicate surgery necessary to graft a right to sue onto a substantive provision. ${ }^{13}$

Thus one point about Nixon $v$. Fitzgerald is immediately apparent: a decision for the plaintiff would have constituted the judicial creation of a particular type of remedy for presidential misconduct. The Court would not have been the umpire, but one of the players. ${ }^{14}$ Judicial activity of this sort is not by itself a bad thing; courts, after all, sit to create remedies as much as they sit to do anything else. ${ }^{15}$ If, however, a decision for Fitzgerald would have meant judicial imposition of a new remedy-one not mentioned in the Constitution-against the President, then the extent of judicial power to do so must be considered.

Before this issue may be discussed in any detail, a second point must be made. The majority opinion in the presidential immunity case may be read in two ways: either as a common law decision or as a constitutional decision. Nixon v. Fitzgerald clearly need not be viewed as a definitive constitutional holding. After all, if an implied right of action is a common law remedy, then the same court that has the power to create the remedy if it is a good idea, has the power to limit its scope. A decision to limit a common law remedy would make a statement about prudence, not about power. If Nixon v. Fitzgerald states a constitutional rule, then future Presidents will be immune from suit. If, on the other hand, the majority merely stayed its hand because to do otherwise at the time would have been imprudent, then the next case might easily be decided differently.

Nowhere does the majority actually state that its decision confers a constitutional immunity, although the opinion includes dicta that may be read to so indicate. ${ }^{16}$ The opinion is, however, full of references to

13 The Court's rhetoric has often treated the process as one of statutory construction, but the conclusion that implied rights of action amount to judge-made law is not so easily avoided. For precisely this reason at least one Justice has recently expressed reservations about the entire implication question, suggesting that the creation of a right to sue is a legislative responsibility and that by creating the right themselves, the Justices may be violating the doctrine of separation of powers. See Cannon v. University of Chicago, 441 U.S. 677, $730-49$ (1979) (Powell, J., dissenting). But see Greene, Judicial Implication of Remedies for Federal Statutory Violations: The Separation of Power Concerns, 53 TEMP. L.Q. 469 (1980) (separation of powers doctrine presents no bar to implication of remedies).

14 This distinction between the roles that the Court plays in different kinds of constitutional adjudication is discussed in somewhat greater detail infra text accompanying notes 107-23.

is See infra text accompanying notes 131-33.

16 See, e.g., Nixon v. Fitzgerald, 457 U.S. at 747 (immunity decisions "have been guided by the Constitution") (emphasis added); id. at 748 ("implicit in the nature of the President's office in a system structured to achieve effective government under a constitutionally mandated separation of powers"); id. at 749 (immunity is "rooted in the constitutional tradition of the separation of powers") (emphasis added). The opin- 
what constitutes proper public policy. At the outset the Court announces that its inquiry will necessarily involve "the kind of "public policy' analysis appropriately undertaken by a federal court."17 Later the majority explains: "Cognizance of . . . personal vulnerability frequently could distract a President from his public duties, to the detriment not only of the President and his office but also the Nation that the Presidency was designed to serve."18 A cause of action against the President, the Court says a few sentences later, is not "needed to serve broad public interests." 19 And in an ambiguous sentence at the end of its opinion, the Court concludes that its rule of absolute immunity will "advance compelling public ends." ing is simply that civil damages liability for the President is not a good idea. The majority opinion makes repeated references to such concepts as "the separation of powers," Court means to suggest that constitutional principles mandate the result, or simply that they help show why immunity is good policy. ${ }^{22}$

There is, of course, nothing unusual in the Court's undertaking

ion contains no express statement along the lines of: "This immunity is required by the Constitution."

17 Id. at 748 .

18 Id. at 753 .

$19 \mathrm{Id}$. at 754 .

${ }^{20} \mathrm{Id}$. at 758. The sentence is ambiguous because a fair reading of it would also be that Fitzgerald's claim was to a remedy "in order to advance compelling public ends." 21 Sep supra note 16.

22 Id. Chief Justice Burger, member of the five-person majority, made clear in his concurring opinion that he considers presidential immunity firmly grounded in the Constitution and the separation of powers. See 457 U.S. 731, 758-64. His opinion also implies that other officials who have been held immune from various types of lawsuits enjoy an immunity that is constitutional in scope. See id. at 764 ("the Court's holding places a President on essentially the same footing with judges and other officials whose absolute immunity we have recognized"). One cannot so easily explain the Court's decisions granting immunity to prosecutors and judges in terms of a constitutionally based immunity. Cases such as Imbler v. Pachtman, 424 U.S. 409 (1976) (state prosecutors), and Stump v. Sparkman, 435 U.S. 349 (1978) (state judges), did not purport to do anything but determine whether the common law tradition and the public interest created an immunity that survived the enactment of 42 U.S.C. $\S 1983$ (1976 \& Supp. V 1981). Although the Court could perhaps have formulated an argument that these immunities are constitutionally mandated, it did not do so in those cases. In particular, nothing in those cases suggested that Congress could not, if it so chose, abrogate the immunity by statute. A state legislature presumably has similar power to abrogate immunity. If, as the Chief Justice seems to suggest, however, state judicial or prosecutorial immunity is conferred by the Constitution, then it could not be abrogated by legislative action. These cases should be distinguished from those involving members of Congress, see infra note 117, which clearly found a constitutionally based immunity from suit.

The fact that the Chief Justice felt it necessary to write the separate opinion that he did suggests that at least one member of the majority regarded the Court's view as less than entirely clear. 
public policy analysis on constitutional issues, and under the Constitution's more open-ended clauses, analysis of this kind is virtually the norm. ${ }^{23}$ The legitimacy of constitutional reasoning is much enhanced, however, when it is tied expressly to the Constitution itself. ${ }^{24}$ When the Court's arguments are not directly tied to the Constitution, as they were not in Nixon $v$. Fitzgerald, the resulting policy analysis is generally open to a scathing retort: "Sez who?" If, on the other hand, the Court merely used its inherent discretion to place limits on a cause of action it had itself created by using common-law authority, then the answer "Sez we" is more than adequate. The common law is what the judges say it is. ${ }^{2 s}$

Thus "presidential immunity decision" must turn out to be something of a misnomer. If the Supreme Court merely decided that it would not extend a judicially-created remedy to the President, because doing so would be a bad thing, then the decision takes on spectacular unimportance. On that reading, Nixon $v$. Fitzgerald decided not a point of constitutional doctrine, but a point of common law. The statement the case made was then about prudence, not about power, and Congress, should it muster the political will, can overturn that statement by legislative action. The fact that the majority reserved the question whether Congress may subject the President to civil damages liability through statute ${ }^{26}$ adds weight to the hypothesis that the case is merely one of common law and therefore decided relatively little.

If Nixon v. Fitzgerald did not decide whether the President possesses an immunity that is constitutional in scope, then the question of judicial power posed so ominously a few paragraphs back remains

23 See, e.g., Little v. Streater, 452 U.S. 1 (1981); Roe v. Wade, 410 U.S. 113 (1973); Griswold v. Connecticut, 381 U.S. 479 (1965).

24 For ambitious attempts to tie some of the Court's "public policy" decisions to the Constitution, see, e.g., Ely, The Wages of Crying Wolf: A Comment on Roe v. Wade, 82 YALE L.J. 920, 928-30 (1973) (defending Griswold); Perry, Abortion, The Public Morals, and the Police Power: The Ethical Function of Substantive Due Process, 23 UCLA L. REv. 689, 723-34 (1976) (defending Roe v. Wade).

${ }^{25}$ That is not to say that the development of common law rules should or can be altogether unprincipled. On the contrary, appeal to principle is essential. The distinction between common law rulemaking and constitutional rulemaking generally lies in the sources of the principles to which the appeal is made. See generally Wellington, Common Law Rules and Constitutional Double Standards: Some Notes on Adjudication, 83 YaLE L.J. 221 (1973).

26457 U.S. at 749 n.27 ("In the present case we ... are presented only with 'implied' causes of action, and we need not address directly the immunity question as it would arise if Congress expressly had created a damage action against the President of the United States."); $c f$. id. at 763 n.7 (Burger, C.J., concurring) ("once it is established that the Constitution confers absolute immunity, ... legislative action cannot alter that result"); id. at 765-66 (White, J., dissenting) (if the Constitution creates the immunity, Congress cannot abrogate it by statute). 
open. ${ }^{27}$ After all, if Congress can constitutionally create a civil damages remedy against the President, then it is hard to imagine what constitutional principles would prevent the federal courts from doing so as well. ${ }^{28}$ Courts were creating remedies for official misconduct long before there was a United States of America, ${ }^{29}$ and nothing in the Constitution appears to have stripped them of that power. ${ }^{30}$ So if Congress is indeed free to overrule the presidential immunity decision, then perhaps no constitutional rule was intended after all.

A judicial opinion, however, is rarely a complete explanation of why a court has decided a case in a particular way. ${ }^{31}$ The Court's statement that the congressional power issue should be left open need not be read as an indication that in the minds of the Justices in the majority, the issue truly is open. Peeking behind the scenes is impossible, ${ }^{32}$ but any number of plausible reasons for "reserving" the question immediately spring to mind. The reservation might have been made to hold a majority, to make the decision more palatable to the public and to scholars, to gain a sixth or seventh vote in order that the outcome seem more decisive, or for some other reason. The reservation might also reflect a genuine concern on the part of one or more of the Justices that the power of the federal courts to create new remedies against the President may be distinguishable constitutionally from the power of Congress to create such remedies. ${ }^{3 s}$

A hypothesis that the Constitution grants broader authority to

${ }^{22}$ The Court has posed the question before, and has even implied an answer. See Mississippi v. Johnson, 71 U.S. (4 Wall.) 475 (1867) (federal court cannot issue order against President), discussed infra text accompanying notes 53-55.

28 But see infra text accompanying 34-39. On the other hand, one can easily imagine principles that would prevent the state courts from assuming the constitutional power to punish the President. State courts are often appropriate forums for the vindication of federal rights, see Testa v. Katt, 330 U.S. 386 (1947), but the federal courts play a special role in the system of checks and balances, see generally THE FEDERALIST No. 51 (J. Madison) (system of checks and balances); THE FEDERALIST Nos. 78 \& 81 (A. Hamilton) (special judicial role).

${ }^{29}$ See P. Schuck, Suing Government: Crtizen Remedies for Official WRONGS 30-36 (1983).

so See, e.g., Bivens v. Six Unknown Agents, 403 U.S. 388 (1971) (implying right to sue from constitutional protections). This should not be taken to suggest that the power to create remedies is without limits. As will become clear, the thrust of this Article is quite to the contrary.

31 See generally W. Murphy, Elements of Judicial Strategy (1964).

32 But see B. Woodward \& S. Armstrong, The Brethren: Inside the SuPREME CouRT (1979) (historical fiction).

ss See Van Alstyne, The Role of Congress in Determining Incidental Powers of the President and the Federal Courts: A Comment on the Horizontal Effect of "The Sweeping Clause," 36 OHIO ST. L.J. 788 (1975) (suggesting that necessary and proper clause generates comparatively broad congressional power to create new remedies against other branches). 
Congress than to the courts to create remedies against the President would not be an unreasonable one. For example, one might argue that because the constitutional system places so many express checks on presidential power directly in the legislative branch, ${ }^{\mathbf{3 4}}$ that branch also ought to have special authority (if anyone has it) to create new ones. After all, legislating is by definition an innovative activity, and any congressional statute dealing with the executive branch is likely to circumscribe presidential authority in some manner. ${ }^{\text {ss }}$ If the Congress can limit the President's authority, why can't it legislate to punish him directly?

The Presidential Recordings and Materials Preservation Act of $1974^{36}$ may be seen as an example of punitive legislation. Every other President has been permitted to collect his papers and dispose of them as he pleased upon leaving the White House. The Act denied that privilege to Richard Nixon. In Nixon v. Administrator of General Services, ${ }^{37}$ the Court upheld the Act against, among other things, a separation of powers challenge. The Gourt conceded that the President had strong claims of confidentiality, but, it explained, in the narrow circumstances surrounding the Nixon resignation, Congress had the power to revoke the President's traditional "privilege" of retaining his papers and effects. ${ }^{38}$ The Act was a creative remedy for presidential misconduct and was upheld even though the Act may have resulted more from congressional pique than from concern for the accuracy of his historical record. The point is that the Court permitted the Congress (whatever its motivation) to act innovatively to impose a punishment that the Court itself could not have imposed..$^{39}$ By analogy, Congress might, in the proper circumstances, have the constitutional authority to create civil damages remedies against the President, even if the federal courts

s4 Several of these checks are discussed in more detail infra, notes 185-203 and accompanying text.

${ }^{35}$ See, e.g., Humphrey's Executor v. United States, 295 U.S. 602 (1935) (sustaining congressional authority to limit President's removal power).

sB 44 U.S.C. § 2107 (1976).

32433 U.S. 425 (1977).

ss Id. at 441-46. The Court did not address other constitutional arguments against the Act's application to specific documents. See id. at 436-39. One commentator has suggested that Nixon retains certain first and fourth amendment rights. See Note, Govermment Control of Richard Nixon's Presidential Material, 87 YALE L.J. 1601 (1978).

so In a proper case, a court can order one who has custody of evidence to preserve it, but the Act went well beyond the need to preserve presidential materials for any particular litigation. The distinction drawn in the text should not be carried too far. To say that a court cannot create the same remedies as Congress can is not to say that the court has less power to create the remedies that it has traditionally created. See infra text accompanying notes 131-56. 
lack power to do so. ${ }^{40}$ If the Constitution gives Congress greater power than it gives the judiciary to create remedies against the President, then the majority's reservation of the congressional power issue does not prevent the decision's being read as a constitutional one or necessitate its being read as a common law one.

This is, of course, sheer speculation. Nevertheless, the mere possibility that the Constitution authorizes broader powers for the Congress than the courts means that the dissent may be correct in characterizing the opinion as stating a constitutional rule. As the dissenters read the majority opinion, the majority has said that something about the Constitution-the majority leaves unclear precisely what-prohibits the courts from creating a civil damages remedy against the President. Because a constitutional immunity is likely-though not certain-to bar Congressional action as effectively as it does judicial action, a finding that the courts cannot impose a particular penalty probably means that the Congress cannot impose it either. ${ }^{11}$ Although safe from judicially and congressionally created remedies, the President would not be "above the law." The only sanctions available in the event of his misbehavior, however, would be those explicitly set forth in or readily inferred from the Constitution itself.

\section{B. What the Court (Might Have) Meant}

The majority denied the charge that its opinion placed the President above the law, ${ }^{42}$ and yet clearly knew that its decision would leave

to Naturally, the mere fact that Congress's authority to legislate to control the President is broad does not imply that the authority is unlimited. As with other congressional powers, it must be exercised in a manner consistent with other provisions of the Constitution and, in particular, must not be used in derogation of the principles of separation of powers. For an important recent reminder of this rule, see Immigration \& Naturalization Serv. v. Chadha, 103 S. Ct. 2764 (1983), discussed infra text accompanying notes $194-202$.

11 Congress might be able to circumvent the presidential immunity decisions (even if the Court meant to establish a constitutional rule) by extending the Federal Tort Claims Act, 28 U.S.C. $\$ \S 2671-2880$ (1976), to encompass actions for damages caused by presidential act or order. Cf. P. ScHuck, supra note 29, at 113-18 (analogous proposal for wrongs by lower-level officials). As long as the defendant in a suit under the amended Act would be the United States and not the President and as long as any judgments would be paid from general revenues and not passed on to the President, then most of the constitutional objections to presidential liability would fall. If the President were asked to produce papers or appear personally in connection with such a suit, considerations of separation of powers would likely permit him to refuse. I am grateful to Martha Minow and Peter Schuck for bringing these points to my attention.

${ }^{12}$ See Nixon v. Fitzgerald, 457 U.S. at 767 (White, J., dissenting) ("the Court clothes the office of the President with sovereign immunity, placing it beyond the law"), and $i d$. at $758 \mathrm{n} .41$ (majority opinion) ("This contention is rhetorically chilling but wholly unjustified."). 
little besides the sanctions explicitly authorized by the Constitution to check the conduct of an evil President. ${ }^{49}$ The majority noted that impeachment and other "formal and informal checks" would remain available. ${ }^{44}$ Unless reliance is placed on historical references that may not bear the weight, ${ }^{45}$ the references to other constitutional sanctions (along with the vague allusions, already mentioned, to the separation of powers) are as close as the majority comes to tying its reasoning to the Constitution itself. The result has an air of expressio unius: because the Constitution creates particular checks on presidential authority, a court may not create fresh ones.

The Gourt cannot really have meant to deny the validity of any check not expressly mentioned in the Constitution. After all, U.S. $v$. Nixon held that the courts can command the President to comply with subpoenas despite the lack of explicit textual support for such a power. Nevertheless, the Court's expressio unius approach may form the basis of a theory explaining the result. ${ }^{46}$ The Presidency (the Court may

4s The term "evil President," like the term "immunity," is used advisedly. Although the lines might be difficult to draw, nothing in the presidential immunity decision suggests that a President who, for example, injured someone through negligence not related to his office would necessarily be immune from suit. Nixon $v$. Fitzgerald by its terms immunizes the President only from suits relating to his official conduct and abuses of his official authority. One possible brightline would distinguish between those things that he is able to do only because he is President and those things that anyone could do. The former would come within the scope of his immunity and the latter would not. Obviously, a private citizen would not have the opportunity to fire a civil servant. The President of the United States might or might not have the authority to do so, but his office would provide the opportunity. There is no need to make too much of this distinction, and some of the arguments in the text admittedly cut against it. This distinction is, however, one approach to making the result in the presidential immunity case more palatable to those who find it distasteful.

4* Nixon v. Fitzgerald, 457 U.S. at 757.

45 The majority consigned its historical discussion to a single lengthy footnote. Id. at 750-52 n.31. Justice White's dissent vigorously disputed the majority's reading of the history, see id. at 771-79, which may be why the Court did not belabor it. The majority could, however, have constructed a stronger historical argument than the one it actually used. See infra notes $69-92$ and accompanying text.

${ }^{16}$ Of course, a demand for theory may be naive or even a cheap shot in these days of doubt as to whether the Supreme Court is institutionally capable of principled decisionmaking. Scholarship from all points on the ideological compass has contributed to the doubt. See, e.g., Brest, Interpretation and Interest, 34 STAN. L. REv. 765 (1982) (interest of decisionmaking elite, rather than positive theory, determines outcome); Easterbrook, Ways of Criticizing the Court, 95 HaRv. L. REv. 802 (1982) (Arrow's theorem demonstrates that no structure can ensure consistent outcomes if Court complies with other norms of judicial decisionmaking); Leedes, The Supreme Court Mess, 57 TEX. L. REV. 1361 (1979) (judicial activism leads inexorably to doctrinal inconsistency); Tushnet, Darkness on the Edge of Town: The Contributions of John Hart Ely to Constitutional Theory, 89 YALE L.J. 1037 (1980) (contradictions in liberal democratic theory make consistent constitutional theory impossible). The conclusions drawn in these articles may be right or wrong; for the purposes of the analysis in this Article, I will pretend that theory is both desirable and important. 
have reasoned) is a political office, and under the constitutional scheme, punishing the President is the responsibility of the overtly political actors-the Congress and the voters. Because of the awesome responsibilities of his office, the President must often worry about the consequences his actions will have for the country but he should not-needlessly-bear the additional burden of fearing for personal consequences to himself. The argument that the President's office and duties are of such a nature as to render him unique in any constitutional analysis has been made too often to bear repeating here. ${ }^{47}$ Suffice it to say that the majority opinion in Nixon $v$. Fitzgerald has some of the flavor of this argument. ${ }^{48}$

Thus (so the majority's analysis could run), the judgment that the President has gone too far, so far that he must be threatened with personal liability even at the cost of distracting him from his official duties, is a difficult judgment and an essentially political one. The question ought to be resolved by the political actors, and that is where the Constitution has wisely placed the express power to check presidential abuses of authority. If this line of reasoning is what actually underlies the presidential immunity case, then the decision begins to make a fair amount of sense and even acquires a certain logical appeal. The line of reasoning resembles that underlying one strand of the "political question" doctrine: the text and structure of the Constitution commit the decision elsewhere, so the federal courts must keep their hands off. ${ }^{49}$ That restraint, because it reinforces judicial legitimacy, remains one of the most powerful arrows in the judicial quiver.

If the preceding two paragraphs fairly state what the majority

47 See, e.g., Bruff, Presidential Power and Administrative Rulemaking, 83 YAle L.J. 451, 467-70 (1979); Van Alstyne, A Political and Constitutional Review of United States v. Nixon, 22 UCLA L. Rev. 116, 130-40 (1974). The most frequent argument for presidential uniqueness is the President's status under the constitutional structure. As Professor Corwin put it: 'The Constitution knows only one 'executive power,' that of the President, whose duty to 'take care that the laws be faithfully executed' thus becomes the equivalent of the duty to and power to execute them himself according to his own construction of them." E. Corwin, The PResident: Office AND Powers 84 (4th ed. 1957) (emphasis deleted); see also infra note 112 and text accompanying notes 127-30.

${ }^{48}$ See 457 U.S. at 757. ("The President is subjected to constant scrutiny by the press," to "[v]igilant oversight by Congress," to "a desire to earn re-election, the need to maintain prestige as an element of Presidential influence, and a . . traditional concern for ... . historical stature.").

48 See, e.g., Gilligan v. Morgan, 413 U.S. 1 (1973); Roudebush v. Hartke, 405 U.S. 15 (1972). A plurality of the Court has taken the position that at least some disputes between the President and Congress should be viewed this way. Goldwater v. Carter, 444 U.S. 996, 1002 (1979) (Rehnquist, J., concurring in the judgment, joined by Burger, C.J., and Stewart and Stevens, JJ.) (right to terminate treaty nonjusticiable). 
meant, then far from collapsing into a narrow statement of federal common law, the opinion in Nixon $v$. Fitzgerald says something tremendously important: the federal courts lack the power to punish the President at all. For if the courts cannot compel him to pay damages to a private individual, it is difficult to see how they could force him to pay damages-in the form of a fine-directly to the court. ${ }^{50}$ And if the courts cannot force him to part with his money, they surely could not order him to jail. Yet those two weapons-deprivation of money and deprivation of liberty-are the only ones that a court can use to force compliance with its mandates. Absent those powers, a court may well issue an injunction or a subpoena, but the court's order may, as Judge Wilkey put it, turn out to be nothing more than a piece of paper bearing the title. ${ }^{51}$ That the court's decision may be ignored does not mean that no process against the President should ever issue; as will become clear, decision and enforcement are logically separable. The possibility that the President might simply disregard the judicial will does mean that if the presidential immunity decision makes a statement about constitutional law, that statement may really be that the federal courts cannot force the President of the United States to do anything at all.

\section{What the Court (Should Have) Said}

The conclusion that the federal courts lack authority to punish the

so One might argue that in the case of a fine for contempt, the Justices are protecting their own sphere-the judiciary-rather than "merely" defending individual rights. If one looks through the other end of the telescope, however, one will note that both cases involve the same issue: can the Court punish the President for doing wrong? The fact that one wrong is done to an individual and the other to an institution (admittedly a coequal one) does not change the question, and there is no immediately apparent reason why it should change the answer.

s1 In the original Watergate-related litigation over whether the President was the proper subject of a subpoena duces tecum-litigation which did not reach the Supreme Court-the United States Court of Appeals for the District of Columbia Circuit stated explicitly that the President's legal obligation to obey a court order did not rest on the court's power to enforce it:

That the Impeachment Clause may qualify the court's power to sanction non-compliance with judicial orders is immaterial. Whatever the qualifications, they were equally present in Youngstown. . . . The legality of judicial orders should not be confused with the legal consequences of their breach; for the courts in this country always assume that their orders will be obeyed, especially when addressed to responsible government officials.

Nixon v. Sirica, 487 F.2d 700, 711-12 (1973) (en banc). The dissent scoffed at this suggestion, arguing that a subpoena naming a party against whom it could not be enforced was no more than "a piece of paper captioned 'subpoena." "Id. at 792 (Wilkey, J., dissenting). The majority opinion adopted the approach advocated here, treating decision and enforcement as logically distinct. 
President of the United States may at first seem somewhat startling, ${ }^{\text {,2 }}$ but after a little thought, it makes more sense. One may begin by hypothesizing the contrary. Suppose a court did try to hold the President of the United States in contempt for disobeying an order addressed to him. Would federal marshals arrive at the White House, demanding that the Secret Service agents let them seize the President? Suppose the President-with the assistance of the security personnel-decided to resist arrest. Aside from a definite air of lese majesty about the whole thing, there is also the undeniable fact that should matters come to a showdown, the President has more guns at his command than a federal court does. The Supreme Court has never pretended otherwise. During the Reconstruction Era, the Court in Mississippi v. Johnson ${ }^{\mathbf{5 3}}$ took explicit note of the difficulties it would encounter in trying to "force" a President to comply with an order, ${ }^{54}$ and dismissed a complaint against President Andrew Johnson. ${ }^{55}$ Earlier opinions included dicta to similar effect. . $^{\text {s8 }}$

The mere fact that forcing the President to pay damages might not be easy does not by itself justify a constitutional rule against trying. ${ }^{.7}$ After all, President Nixon did turn over the Watergate tapes, even though the federal courts probably could not have enforced a contempt citation against him. ${ }^{58}$ Besides, resistance to judicial decrees is hardly

52 The usual rule is quite the contrary: even claims of fundamental right are no defense in a contempt proceeding for ignoring an injunction. See Walker v. City of Birmingham, 388 U.S. 307 (1967). The thrust of the presidential immunity decision (and of this Article as well) is that when it comes to court orders, the President is a special case. I am grateful to Robert Cover for reminding me that the courts frown on claims of a "right" to ignore their orders.

ss 71 U.S. (4 Wall.) 475 (1867).

se Se id. at 500-01: "[I]t is needless to observe that the court is without power to enforce its process."

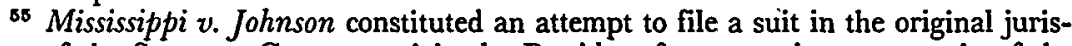
diction of the Supreme Court to enjoin the President from carrying out certain of the Reconstruction Acts. Consequently, Mississippi v. Johnson might be distinguishable from a case like Nixon v. Fitzgerald because the former involved a suit against the President for performance of a mere ministerial act. See Karst \& Horowitz, Presidential Prerogative and Judicial Review, 22 UCLA L. REv. 47, 50-51 (1974) (suggesting this limited construction).

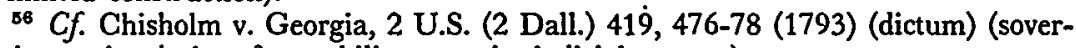
eign immunity derives from ability to resist judicial process).

87 If the mere possibility of presidential resistance sufficed to trigger presidential immunity, it would not be easy to draw lines between the President and his subordinates, many of whom could also-especially with presidential assistance-resist the orders of a court. As will become clear, the President's power is important, but something more is required before immunity is appropriate. There is a distinction, moreover, between judicial restraint and judicial cowardice, a distinction discussed in greater detail infra, text accompanying notes 161-69.

${ }_{58}$ President Nixon's decision to yield the tapes need not be read as an acknowledgement of judicial authority. He may simply have been bowing to political reality. 
new. ${ }^{69}$ Had the President not decided to send troops to Little Rock in the wake of Cooper $v$. Aaron, ${ }^{60}$ the schools in that city might be segregated to this day. ${ }^{61}$ The Court's inability to enforce its order without the assistance of the executive branch did not mean that the Justices had no power to issue the order. Thus the claim that the Court lacks power to punish the President must be defended on some ground other than the Court's lack of enforcement power.

In supporting its conclusion in Nixon $v$. Fitzgerald, the majority focused on what it considered the public policy reasons militating in favor of an immunity rule. Justice White's dissent at least showed that these arguments have two sides. ${ }^{62}$ The malleability of public policy arguments makes the majority's reasoning suspect, but need not vitiate the result. In order to tie its decision more closely to the Constitution, the Court could have relied on something other than public policy.

Before suggesting some justifications that, although available, were absent from the majority opinion, it is useful to pause and recall what the case did not involve. ${ }^{63}$ The Gourt was not required to construe the Constitution's "open-ended" provisions protecting individual rights against government abuse. The dilemma whether to read those clauses as though the Constitution were a statute-or perhaps a contract-or to take them as invitations to import extra-constitutional values motivates much contemporary scholarship on constitutional theory. ${ }^{64}$

See infra note 113.

89 Historic incidents of resistance are collected in J. Choper, Judicial Review and the National Political Process 140-50 (1980).

30 U.S. 1 (1958).

61 The text may be a bit unfair; times have changed. The unanswered question remains one of chicken and egg-is integration more widely accepted because the courts have been successful in ordering it, or have the courts succeeded in ordering it because it is more widely accepted?

${ }^{62}$ See Nixon v. Fitzgerald, 457 U.S. at 792-97 (White, J., dissenting) (attacking the majority's "public policy" approach). See also Note, supra note 8, at 231 ("Far from supporting Justice Powell's result, considerations of public policy point toward a grant of qualified, not absolute, presidential immunity").

${ }^{\text {os It }}$ is also useful to pause and recall that an argument that the presidential immunity decision could have been more powerfully reasoned is not the same as an argument that the case was rightly (or wrongly) decided. Constitutional theorists seek constitutional theory, in "good" decisions as well as in "bad" ones. The search for a theory to undergird the result in Nixon $v$. Fitzgerald is necessary, both to learn whether it can be harmonized with past decisions and to try to discern what messages it might carry for future ones.

ot Although citations for this point would probably be a bit gratuitous, some of the major currents in this muddy river might be discerned through a perusal of the widely divergent views expressed in the following four recent works: R. BERGER, GoverNMENT By Judiciary (1977); J. Ely, Democracy and Distrust (1980); M. PerRy, The Constitution, the Courts, and Human Rights (1982); L. Tribe, American Constitutional Law (1978). 
Happily, determining whether a reasoned constitutional basis exists for the presidential immunity decision does not require wading into the midst of that scholarly battle. Whatever the best approach to the adjudication of claims under the clauses protecting individual rights (and it is not at all clear that there need be only one), there is no apparent reason to believe that the same interpretive approach ought to apply to other constitutional provisions. ${ }^{65}$ Different sections of the document have different purposes and interpreting each in light of its purpose will probably lead to drastically different approaches. Thus, it is one thing to look to extra-constitutional sources in deciding what rights are "retained by the People"s8 or incorporated in the phrase "Privileges or Immunities;","8z it is something else altogether to do so when considering whether federal courts can, for example, review a presidential decision to cast a veto-or whether the President is a proper defendant in a suit seeking civil damages.

Provisions describing the functions and powers of the government may demand a different interpretive approach from provisions describing the rights of the people. A strict textual approach, focusing on the understanding of the Framers, may be a more sensible method to use in interpreting the structural clauses of the Constitution. ${ }^{68}$ Whether it is a more sensible method will be examined in the next few pages. If the strict textual approach does make more sense, then the majority's public policy analysis is probably inadequate to justify a constitutional rule of immunity. It is therefore necessary to consider other possible justifications for the presidential immunity decision.

Bs Professor Ely has implied (although he probably didn't mean it) that constitutional theorists should develop a single theory to explain adjudication under the entire Constitution. See J. ElY, supra note 64, at 41 n.* ("the Constitution is not divided into two sets of provisions, precise and open-ended"). In truth, some provisions of the Constitution, such as the requirement that the President be thirty-five years of age, are indeed more precise than others, such as the equal protection clause. Ely is apparently prepared to concede this disparity. See id. at 13 ("Constitutional provisions exist on a spectrum ranging from the relatively specific to the extremely open-textured"). Although Ely devotes much of his book to suggesting a single approach, it is not at all clear why a single approach is needed to explain all of the document's provisions, precise, open-ended, and merely muddy.

${ }_{6 B}$ U.S. CoNST. amend. IX.

67 U.S. ConsT. amend. XIV.

68 On the other hand, it may not. See Brest, The Misconceived Quest for the Original Understanding, 60 B.U.L. REv. 204, 237 n.124 (1980) ("Analytically and normatively, I see no essential differences among the various areas of constitutional concern that would automatically insulate any of them from the possibility of nonoriginalist decisionmaking"); Saphire, The Search for Legitimacy in Constitutional Theory: What Price Purity?, 42 OHIO ST. L.J. 335, 337-38 (1981) (debate over best means of constitutional interpretation includes "major provisions regarding the . . . allocation [of] government power" when they are "quite general in [their] scope and delphic or ambiguous in [their] language"). 


\section{The Original Understanding Approach}

As a general rule, scholars frown on attempts to construe the Constitution by surveying the opinions of the eighteenth-century gentlemen who wrote it and voted on its ratification. ${ }^{69}$ The Supreme Court, on the other hand, rarely permits a constitutional case to go by without discussing the "original understanding."" The original understanding-when one can be discerned-is more likely to be important in a case involving the system of checks and balances than it is in a case involving individual rights. The reason should be obvious. In protecting individuals against government mistreatment, those who drafted the 1787 Constitution and its amendments took pains to use language so broad as fairly to beg to be filled with substantive content from external sources. They used words sparingly, an approach that makes sense when one begins with a conception of rights as broad and government power as narrow. ${ }^{71}$ In structuring the government, however, the drafters set themselves rather a different task and used dramatically different language.

The 1787 Constitution set forth with painstaking attention to detail the powers and functions of the federal government. Despite a few glaring errors, ${ }^{72}$ the document reflects an obsessive concern for the minutiae of government operation. ${ }^{73}$ Words were used cautiously so as to

69 See, e.g., A. Bickel, The Least Dangerous Branch 98-110 (1962); J. Ely, supra note 64, at 11-41; M. PERRY, supra note 64, at 20-24, 61-72; Brest, supra note 68; Munzer \& Nickel, Does the Constitution Mean What it Always Meant?, 77 Colum. L. Rev. 1029 (1977).

${ }^{20}$ But cf. Kelly, Clio and the Court: An Illicit Love Affair, 1965 SuP. CT. Rev. 119 (asserting that the Justices use history badly because they twist it in order to support the results that they desire). See also Professor Laycock's stinging evaluation of the work of Raoul Berger (perhaps the most prolific contemporary advocate of paying close attention to the original understanding), quoted infra note 79.

${ }^{21}$ See generally B. Bailyn, The Ideological Origins of The American Revolution (1967); G. WoOd, The Creation of the AMErican Republic, 17761787 (1969); Grey, Origins of the Unwritten Constitution: Fundamental Law in American Revolutionary Thought, 30 STAN. L. Rev. 843 (1978).

72 A good example concerns the role of the Vice President. The Vice President serves as President of the Senate. U.S. Consr. art. I, § 3. When the President of the United States is tried in the Senate following impeachment by the House of Representatives, the Chief Justice of the United States presides. Id. That is the only provision in the Constitution requiring the Vice President to turn over the gavel to another individual. Yet the Vice President himself is also impeachable, and if impeached by the House, he would be tried in the Senate. It appears, therefore, that the Vice President could preside at his own impeachment trial, should he choose to do so.

7s This "obsession" with detail is only comparative. Few words in the document are used in defining the rights of the people. Many are used in explaining the operation of government. The details set forth in the Constitution often give inadequate guidance for the operation of the modern activist state, the rise of which the Framers could not, of course, have anticipated. See note 199 infra. That their obsession did not pro- 
leave little room for interpretation. Thus although some wanted to make the President impeachable for any reason, the delegates in Philadelphia finally voted to limit impeachable offenses to "Treason, Bribery, or other high Crimes and Misdemeanors, ${ }^{374}$ in the hope of limiting congressional power over him. ${ }^{75}$ The Constitution also does not include a requirement that members of the House of Representatives be "mature"-although maturity emerged as a major concern in the debates $^{76}$ - but only that they be at least twenty-five years old. ${ }^{27}$ One can

duce perfect prescience does not mean that the obsession did not exist.

74 U.S. ConsT. art. II, \& 4.

7s See 2 Records of the Federal Convention 550 (M. Farrand ed. 1911) [hereinafter cited as RecoRDs]. The Committee of Eleven had recommended limiting impeachment to cases of treason or bribery. Mason responded that many abuses of power would not fall within those narrow categories, and suggested the substitution of "maladministration." But Madison, who drafted the phrase "high crimes and misdemeanors," argued that Mason's proposal was "[s]o vague a term" that it would "be equivalent to a tenure during the pleasure of the Senate." Madison's phrasing was adopted. Id. For a concise summary of the contemporary debate over which offenses ought to be impeachable, see G. Gunther, Cases and Materials on ConstituTIONAL LAW 430-31 (10th ed. 1980).

${ }^{78}$ Madison's notes on the Convention recite the following:

Col. Mason moved to insert "twenty five years of age as a qualification for the members of the 1st branch". He thought it absurd that a man today should not be permitted by the law to make a bargain for himself, and tomorrow should be authorized to manage the affairs of a great nation. It was the more extraordinary as every man carried with him in his own experience a scale for measuring the deficiency of young politicians; since he would if interrogated be obliged to declare that his political opinions at the age of 21 were too crude and erroneous to merit an influence on public measures. It had been said that Congs. had proved a good school for our young men. It might be so for any thing he knew but if it were, he chose that they should bear the expense of their own education.

1 ReCORDS, supra note 75 , at 375 . James Wilson challenged the assumption that the young were immature: "Many instances might be mentioned of signal services rendered in high stations to the public before the age of $25 . " I d$. The motion to make twenty-five the minimum age nevertheless carried by a vote of seven states to three, with one delegation undecided.

A similar reduction of vague qualifications to a term of years appears in Tench Coxe's pseudonymous discussions of the President and members of the Senate, published in a Pennsylvania newspaper during the ratification debates under the byline "An American Citizen." Of the President, Coxe wrote:

$[\mathrm{H}] \mathrm{e}$ cannot be an idiot, probably not a knave or a tyrant, for those whom nature makes so, discover it before the age of thirty-five, until which period he cannot be elected. . . . Our President must be matured by the experience of years, and being born among us, his character at thirty-five must be fully understood.

2 Documentary History of the Ratification of the Constitution 140-41 (M. Jensen ed. 1976) (emphasis deleted) [hereinafter cited as Documentary HrsTORY]. Coxe noted of Senators: "No ambitious, undeserving or unexperienced youth can acquire a seat in this house by means of the most enormous wealth or most powerful connections, till thirty years have ripened his abilities and fully discovered his merits to his country. . . ." Id. at 143 (emphasis deleted).

77 U.S. Const. art. I, §2, cl. 2. 
imagine a Constitution providing that elected representatives be "mature" or "of good character," but there is something disturbing, perhaps counterintuitive, about such provisions, as there would be about a provision for congressional overriding of the President's veto "by an extraordinary majority," unless the provision specified what the majority must be. These hypothetical provisions seem counterintuitive for a good reason, and that good reason probably explains their absence from the Constitution: in determining such matters as the qualifications for elected officials, the Framers were structuring a government, not setting forth rights. In the Framers' view, the former called for more precise language than did the latter. The precise wording of the structural provisions reflects an effort to define the structure of government carefully and circumscribe the powers of government narrowly. This purpose should not be ignored when construing the structural provisions of the Constitution.

It therefore makes sense to try to determine the way that the Framers hoped that the Presidency would be controlled. ${ }^{78}$ The hopes of the Framers may not be decisive and certainly should not be relied on when they contradict the textual language, ${ }^{70}$ but they can shed light on the proper operation of the system of checks and balances. Naturally, the Framers were rarely, if ever, unanimous, and even a consensus would be difficult to establish. Anyone who claims to have found unequivocal agreement should be treated with the degree of respect that argument deserves. Justice Powell was surely correct, however, when he wrote for the majority in Nixon $v$. Fitzgerald that "historical evi-

${ }^{78}$ The argument that the original understanding sheds light because of the nature of the clauses under analysis should be distinguished from the argument that the original understanding matters because the Framers wanted it to. The latter argument is a tautology that has properly been labeled "anomalous." See Kay, Preconstitutional Rules, 42 Oнiо ST. L.J. 187, 193 n.22 (1981).

79 Compare the following critique of the work of Raoul Berger on the fourteenth amendment:

[N]o amount of legislative history can change the meaning of the text as extensively as some would wish. Professor Berger assures us that the intention of the Framers is "as good as written into the text," by which he means "substituted for the text." Had the fourteenth amendment said, "Never hurt black Southerners," he would not let that bar an argument from legislative history to show that it really meant "Always help white Northerners." Legislative history cannot perform such feats. It can clarify ambiguities, indicate central concerns, and cast light on whether cases near the limits of the language were meant to be included. But it cannot do what Berger requires of it. . . .

Laycock, Taking Constitutions Seriously: A Theory of Judicial Review, 59 TEx. L. REv. 343, 351-52 (1981) (footnotes omitted) (review of J. ELX, supra note 64). 
dence must be weighed as well as cited."80 The majority weighed the evidence and concluded that the original understanding lent some support, but not too much, to its argument. ${ }^{81}$ In truth, the majority could have made more of the history than it did. The great weight of the historical evidence suggests the existence of a consensus at the time of ratification to the effect that those checks on presidential abuse of power expressly set forth in the document were the only checks available. $^{82}$

This consensus emerges from the nature of the disputes among the drafters and ratifiers over the proper functions and powers of the President. The intense debate surrounding the Presidency induced the Framers to define their views with rare precision. Those who favored a loose confederation of quasi-independent states argued that the President was too strong and not sufficiently accountable for wrongdoing, ${ }^{83}$

so 457 U.S. at 752 n.31.

81 In a lengthy historical footnote, the majority cites the following evidence: (1) concerns expressed at the Constitutional Convention that even impeachment might be too great a burden on the President; (2) the total absence of suggestions at that time that personal damages liability was contemplated; and (3) various remarks in the early years of the Constitution. Explicitly recognizing the "fragmentary" character of these sources, Justice Powell's footnote goes on to add that "the most compelling arguments arise" not from the history, but from the structure of the Constitution. Id.

82 The word "consensus" is used here in a quasi-scientific sense. "Consensus" does not connote unanimity, but rather a common understanding reflected in the shared views of an overwhelming majority. The majority view may be wrong, but even those in the minority will generally concede that the majority view exists. See M. WESSEL, Science and Conscience 142-44 (1980); J. Ziman, Reliable Knowledge: AN EXPLORATION OF THE GROUNDS FOR BELIEF IN SCIENCE 88-92, 124-26 (1978). Thus the mere existence of a handful of contemporaneous statements arguably to the contrary does not defeat the notion that a consensus existed, as long as the primary evidence is concrete and powerful. This approach to the original understanding is close to, but not quite the same as, what Professor Brest calls "moderate originalism." Brest, supra note 68 , at 231-34.

8s Some delegates made statements to this effect at the Constitutional Convention, but the argument arose far more frequently and powerfully after the document was submitted to the states for ratification. For statements at the Convention, see, e.g. 1 RECORDS, supra note 75, at 101 (J. Mason) ("We are not indeed constituting a British Government, but a more dangerous monarchy, an elective one"). Arguments during the ratification debates are set forth at, e.g., 3 DOCUMENTARY HISTORY, supra note 76, at 374 (Newspaper correspondent argues that President would be "vested with the powers of [a] King"); 4 Debates in the Several State Conventions on the Adoption OF THE FEDERAL Constitution 314 (J. Elliot ed. 1836) (J. Lincoln) ("impossible" to remove the President "without another revolution") [hereinafter cited as DEBaTEs]; 3 id. at 165-66 (P. Henry) ("Can you search the President's closet? Is this a real check?"); id. at 219 (J. Monroe) ("I can see no real checks [on the President] in it"); id. at 491 (W. Grayson) (impeachment inadequate as sole remedy, because President and Senators may be "partners in crime"). See generally Kenyon, Men of Little Faith: The Anti-Federalists on the Nature of Representative Government, in THE CONFEDERation and the Constitution: The CRitical Issues 56, $72-74$ (G. Wood ed. 1973). 
those who thought the central government should be strong argued that the President was too weak, that he was subject to too many controls and potential punishments to be able to do his job properly. ${ }^{84}$ Supporters of the Constitution had ready responses to each objection.

The President was not too strong, supporters contended, because he was subject to several specific checks on abuses of his authority. ${ }^{85}$ The supporters always listed the checks appearing in the document: the power of the purse rested with Congress, the President could be impeached, his veto could be overridden, he could make no appointments or treaties without Senate consent, he was subject to reelection every four years. ${ }^{86}$ Hamilton went to great lengths in The Federalist to assure the worried public that these provisions were adequate to control presidential misconduct. ${ }^{87}$ At the same time, Hamilton and other sup-

84 For examples of this argument during the Philadelphia Convention, see, e.g., 1 RECORDS, supra note 75 , at 98 (J. Wilson) (if veto is not absolute, "the Legislature can at any moment sink [the executive] into non-existence"); 2 id. at 64-65 (G. Mason) ("impeachment will be nearly equivalent to a displacement, and will render the Executive dependent on those who are to impeach"). In the Pennsylvania ratification process, all but two of the delegates voting against ratification signed a minority report charging, among other things, that the strength of the Senate "will destroy all independency and purity in the executive department." DOCUMENTARY HISTORY, supra note 76, at 635. Similar arguments persisted throughout the debates. See, e.g., 4 DEBates, supra note 83, at 117 (S. Spencer) (combination of impeachment and veto powers renders Chief Executive helpless). Some of these complaints, however, might be dismissed as sour grapes, in light of the preference of some Federalists for a monarchy. See generally G. Wood, supra note 71, at 205; Krauel, Prince Henry of Prussia and the Regency of the United States, 1786, 17 AM. HrsT. REv. 44 (1911). During the presidencies of George Washington and John Adams, a quasi-monarchical conception of the presidency may have attained broad popular acceptance. See E. CoRwin, ThE PREsident: OFFICE AND Powers 1787-1957, 17 (rev. ed. 1957). In fact, Washington (who no one doubted would be the first President) is said to have preferred the title "His High Mightiness, the President of the United States and Protector of their Liberties." $M$. Farrand, The Framing of the Constitution of the United States 163 (1913).

ss See, e.g., 2 Debates, supra note 83, at 200-01 (R. Law) (popular election will "secure" the people from "oppression"); 3 DocumenTARY HISTORY, supra note 76, at 527 (R. Sherman) (similar); 3 DEBATES, supra note 83, at 486 (E. Randolph) ("If he be not impeached, he may be displaced at the end of the four years"); 4 id. at 122 (W. Davie) ("impossible for human ingenuity to devise any mode of election better calculated to exclude undue influence"): $i d$. at 32 (J. Iredell) (impeachment renders President "amenable for his conduct"); id. at 281 (C. Pinckney) (abuses of power "effectually checked" because "[n]o man, however great, is exempt from impeachment and trial").

${ }^{80}$ See supra note 85 . The Framers expected that the desire for reelection would serve as one of the most important checks on presidential abuse of his authority. They did not reckon on advancing technology that would permit implementation of presidential decisions in a relatively short period of time. They also did not foresee the adoption of the twenty-second amendment.

87 [The President] is to be elected for four years; and is to be reeligible as often as the people of the United States shall think him worthy of their confidence. In these circumstances there is a total dissimilitude between 
porters of ratification repeatedly warned that no additional checks should be permitted, lest the President become too weak. ${ }^{88}$

The Constitution's supporters made, with slightly different emphasis, the same argument to those who thought the Constitution made the executive too weak. In reassuring those who feared presidential weakness, supporters emphasized that the limitations actually stated in the Constitution were the only limitations placed on the President, and these, the opponents were assured, would not impair the President's ability to do his job. ${ }^{89}$ Some provision had to be made against the possi-

him and a king of Great Britain, who is an hereditary monarch, possessing the crown as a patrimony descendible to his heirs forever. . . .

The President of the United States would be liable to be impeached, tried, and, upon conviction of treason, bribery, or other high crimes and misdemeanors, removed from office; and would afterwards be liable to prosecution and punishment in the ordinary course of law. The person of the king of Great Britain is sacred and inviolable; there is no constitutional tribunal to which he is amenable; no punishment to which he can be subjected without involving the crisis of a national revolution. . . .

The President of the United States is to have power to return a bill, which shall have passed the two branches of the legislature, for reconsideration; and the bill so returned is to become a law, if, upon that reconsideration it be approved by two thirds of both houses. The king of Great Britain, on his part, has an absolute negative upon the acts of the two houses of Parliament. . . . The qualified negative of the President differs widely from this absolute negative of the British sovereign. . . .

The Federalist No. 69 at 444-45 (A. Hamilton) (B. Wright ed. 1961) (emphasis in original).

${ }_{88}$ See, e.g., 4 Debates, supra note 83, at 315 (C. Pinckney) (arguing against alterations in President's term of office); id. at 74 (J. Iredell) (explaining why President must have veto). This was all part of a larger effort by supporters of ratification to avoid any changes in the carefully crafted system of checks and balances.

For example, an anonymous newspaper article in New Jersey insisted that "every guard which can be reasonably required seems to be made against improper encroachment." 3 DocumentaRy History, supra note 76, at 148-49. A New York delegate warned his state's ratifying convention: "We may render useless all our provisions for security by urging and straining them too far: we may apply checks which have a direct tendency to impede the most salutary operations of the government, and ultimately deprive it of the strength and vigor necessary to preserve our national freedom." 2 Debates, supra note 83, at 297 (G. Morris). New York Chancellor Robert Livingston agreed, suggesting that those who wanted to add additional limitations "would multiply checks till the new government was as relaxed and nerveless as the old one." Id. at 323. Added Rawlin Lowndes in the South Garolina Convention: "[T]0o many checks in a political machine must produce the same mischief as in a mechanical one-that of throwing all into confusion." 4 DEBATES, supra note 83 , at 309.

89 James Wilson in particular told the Pennsylvania ratification convention that he had expected only the charge that the President was too powerful, not the charge that he was not powerful enough. 2 DeBates, supra note 83, at 510-11. "I do not mean to insinuate that he has more powers than he ought to have," Wilson added, "but merely to declare that they are of such a nature as to place him above expression of contempt." Id. at 512-13. John Adams, an influential Federalist who would later become the first Vice President and the second President, asserted that even with all the checks spelled out in the document, the power of the Chief Executive "during those 
bility of presidential tyranny, supporters pointed out, and the drafters had done the best they could without limiting the Chief Executive's powers too greatly. ${ }^{80}$

There is no reason to belabor this; attempts to piece together an original "understanding" from the fragments of history tend to end up looking silly. ${ }^{91}$ What is rather startling in this instance is that the same questions and answers occur again and again in the surviving records. That is why it may be safe to assume that a consensus existed. At the very least, it cannot fairly be asserted that the history points in some other direction. ${ }^{92}$

four years is much greater than that of an avoyer, a consul, a podesta, a doge, a stadtholder; nay, than a king of Poland; nay, than a king of Sparta." G. WooD, supra note 71, at 586 (quoting Adams). See also The Federalist Nos. 73, 74 \& 75 (A. Hamilton) (Chief Executive retains vigor in spite of checks on him).

80 During a discussion of impeachment at the Constitutional Convention, delegate after delegate rose to defend this check. William Davie suggested that if the President "be not impeachable whilst in office, he will spare no efforts or means whatever to get himself re-elected." 2 RECORDS, supra note 75, at 64 . Without the remedy of impeachment, George Mason said, the Chief Executive would be "above Justice." Id. at 65. James Madison asserted that impeachment was necessary because it was "indispensable that some provision should be made for defending the Community ag[ainst] the incapacity, negligence or perfidy of the chief Magistrate," who could otherwise freely "pervert his administration into a scheme of peculation or oppression" or "betray his trust to foreign powers." Id. at 65-66. Edmund Randolph added that without impeachment, "no regular punishment" would exist should the President abuse his powers. Id. at 67. And Benjamin Franklin commented wryly that without impeachment, recourse might be had to assassination, in which event the President would be "not only deprived of his life but of the opportunity of vindicating his character." Id. at 65 . It was on the strength of these arguments that the Convention voted overwhelmingly to retain the remedy of impeachment and removal from office. Similarly, in his state's ratifying convention, James Iredell warned that without the congressional power of impeachment, the President would know "that there is no tribunal to punish him" for "misconduct" and therefore he "may be ready to deviate from his duty. . . ." 4 DEBATES, supra note 83 , at 32 .

${ }^{91} \mathrm{Or}$, at least, piecing together the original understanding may seem silly from a lawyer's point of view; lawyers generally think that only evidence that is clear and convincing "proves" a point. Historians are accustomed to operating at a lower level of confidence, and good historians willingly express a concomitantly higher level of doubt as to their conclusions. The text's suggestion that a consensus probably existed is certainly open to attack. That the same pattern of questions and answers was repeated so often in the debates over the Constitution, however, remains remarkable. The consistent pattern does not "prove" that a consensus existed, but it certainly places the burden of persuasion on the other side.

92 Justice White's valiant effort to do so in his Nixon $v$. Fitzgerald dissent comes close but falls short. First, Justice White quotes the governor of North Carolina's speech to his state's ratification convention to the effect that an officer who is liable to impeachment may, if he "commits an offense against an individual" be "amenable to the courts of law." Nixon v. Fitzgerald, 457 U.S. at 774 (quoting 4 DEBATES, supra note 83, at 48 (S. Johnston)). The governor's comment, however, came in response to a hypothetical case involving an inferior officer engaged in ministerial duties. See $4 \mathrm{DE}$ BATES, supra note 83, at 46-48 (A. Maclaine). Consequently, it does not bear on punishment of the President, who was treated throughout the debates as a special case. 
[Vol. 131:1341

\section{The Structural Approach}

The Constitution's relatively precise clauses describing the operation of the federal government are designed to fit together to form a coherent structure. This purpose distinguishes them from the open-ended clauses, many of which were designed to address particular problems and bear little relation to the other parts of the document. By careful attention to the structure of the system of checks and balances created by the more precise clauses, the majority could have tied its opinion more closely to the Constitution.

The system of checks and balances is a delicate one, and the Constitution sets forth with some degree of care the checks that each branch may apply to the others. Thus the President may nominate and, if the Senate consents, appoint Justices to the Supreme Court and judges to the lower federal courts, ${ }^{83}$ but only Congress, through impeachment

Justice White quotes another North Carolina delegate: "Were it possible to suppose that the President should give wrong instructions to his deputies, whereby the citizens would be distressed, they would have redress in the ordinary courts of common law." 457 U.S. at 774-75 (quoting 4 DEBATES, supra note 83, at 47 (A. Maclaine)). This remark, however, occurred in the course of the hypothetical that gave rise to Governor Johnston's comment quoted above. The context makes plain that Maclaine was referring to the proper forum for relief, not to the proper defendant. Nothing in the presidential immunity decision is to the contrary; the only issue is whether the defendants in this hypothetical case would be the President and his aides or his aides alone. See infra notes 208-19 and accompanying text. On that point, Maclaine's comment gives no clue.

Justice White next quotes Wilson, who told the Pennsylvania convention that "far from being above the laws, [the President] is amenable to them in his private character as a citizen, and in his public character by impeachment." Nixon v. Fitzgerald, 457 U.S. at 775 (quoting 2 DEBATES, supra note 83 , at 480 ). If other significant evidence supported Justice White's construction of this comment, the comment might be taken to stand for the proposition for which he cites it. By itself-or more precisely, against the historical backdrop discussed supra text accompanying notes 72-91-it only suggests that when the President does a purely private wrongful act (failure to pay income tax, for example), he violates the law. Wilson's comment hardly suggests the appropriate remedy, and it says nothing at all about prospective civil liability when the President acts in a public character but abuses his powers. See supra note 43. Finally, Justice White consigns to a footnote what is probably the strongest evidence in support of his historical understanding: a pseudonymous essay by Tench Coxe in which he states that the person of the President "is not so much protected as that of a member of the House of Representatives; for he may be proceeded against like any other man in the ordinary course of law." 457 U.S. at 774 n.14 (quoting 2 DOCUMENTARY HISTORY, supra note 76 , at 141) (emphasis in the original). That quotation represents one of those pieces of evidence in which a historian can find whatever he may be looking for. The quotation could refer to civil damages liability, but in light of the historical context more likely refers either to proceedings after impeachment (because the speech or debate clause's protection of a member of Congress can never be removed) or to the opinion of a single essayist. When balanced against the apparent consensus that no other checks existed but those set forth plainly in the document, the quotation cannot carry too much weight.

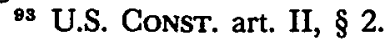


and conviction, may remove them. ${ }^{94}$ Congress may propose legislation (including legislation channeling the President's discretion), ${ }^{95}$ but absent extraordinary majorities in both Houses, the proposals do not become law if the President objects. ${ }^{96}$ Congress may go through the motions of enacting legislation that violates the Constitution, but the federal courts, in a case properly brought, may strike those statutes down. ${ }^{87}$ Congress holds exclusive power of the purse, ${ }^{88}$ and Congress alone can impeach the President and remove him from office. ${ }^{99} \mathrm{~A}$ few other checks, mostly in the form of congressional powers, are scattered through the document. ${ }^{100}$ In addition, because all members of Congress as well as the President are elected, popular sentiment provides a powerful and constant check on the operation of the entire system. ${ }^{101}$ Outside the interplay of these powers, the Constitution provides no further express controls on misconduct.

As American society has evolved, powerful arguments have arisen that other checks-checks for which the Constitution makes no apparent provision-ought to be applied against any one of the three branches in order to control its growing power. New remedies insti-

94 Id. art. I, \& 3 (implying that anyone holding "any office of honor, Trust, or Profit under the United States" may be subject to impeachment and trial). See R. BERger, Impeachment: The Constitutional Problems 122-65 (1973).

${ }^{85}$ Although the modern Supreme Court has occasionally intervened when congressional supervision of the other branches has been too close, see, e.g., Buckley v. Valeo, 424 U.S. 1 (1976) (congressional usurpation of some executive responsibilities), Congress has generally been able to curtail executive discretion, through direct legislation, see, e.g., Train v. City of New York, 420 U.S. 35 (1975) (Congress may force the executive branch to spend money).

o U.S. CoNST. art. I, \& 7.

97 See Marbury v. Madison, 5 U.S. (1 Cranch) 137 (1803) (power to declare laws unconstitutional may be implied from constitutional structure).

${ }^{28}$ U.S. ConsT. art. I, \& 8.

89 Id. art. I, $\S 2$ (House has sole impeachment power); id. art. I, $\S 3$ (Senate has sole power to try impeachments). After impeachment and removal, the President is "liable and subject to Indictment, Trial, Judgment and Punishment, according to Law." Id: Arguably, because it removes any possible separation of powers defense to a criminal proceeding, impeachment would also strip the President of his immunity from civil damages liability.

${ }_{100}$ See, e.g., id. art. I, $\$ 8$ (Congress may declare war); id. art. II, § 2 (Senate must approve treaties and major appointments); $i d$. art. V (as construed in Hollingsworth v. Virginia, 3 U.S. (3 Dall.) 378 (1798)) (President has no role in constitutional amendment process).

101 See $i d$. art. I, $\S 2$ (members of House elected by public every two years); $i d$. art. I, $\S 3$, amended by amend. XVII (members of Senate elected by public every six years); id. art. II, $\S 1$ (President and Vice President elected every four years). Because members of the House serve the shortest terms, public pressure on them may be greater than that on Senators and on the President. If so, members of the House might forge that additional pressure into a club to hold over the Senate and the Executive Branch.

For some of the ways in which public opinion might influence the Justices of the Supreme Court, see infra notes 158 \& 170 and text accompanying notes 158-70. 
tuted by Congress included statutes restricting the President's power to remove executive branch functionaries. The first such statutes were struck down, but later versions were sustained. ${ }^{102} \mathrm{~A}$ more recent example of an attempt to restrict the presidency was the congressional creation of the "legislative veto," through which Congress attempted to influence day-to-day policymaking in the executive branch and in the administrative agencies without affording the President an opportunity to exercise his constitutional prerogative by casting a veto. ${ }^{103}$ If the presidency has become "imperial"104 and if none of the existing restraints seems sufficient to rein in whatever maniac might then be occupying the Oval Office, the idea of creating a new remedy has a certain appeal. But in entrusting to any one branch of government the authority to create new checks on one or both of the others, the proponent of the new check is inviting one branch to act unilaterally to alter the delicate balance that the Constitution creates. At the risk of sounding melodramatic, those who advocate the creation of new checks are, however unintentionally, ultimately seeking to subvert the balance of powers in order to save it. It is difficult to see how the checks built into the structural provisions of the Constitution will retain their intended force if they are not tempered by a continuing balance.

The balance of powers among the three branches of the federal government is a delicate construct, and if any one of the branches is empowered to create new checks on the others that branch will be in the position to upset the very balance that it purports to protect. Thus the system requires placing the narrowest possible reading on the authority of each branch of government to act in the name of preserving that system. ${ }^{105}$ Attention to the original understanding and a strict view

102 Compare Myers v. United States, 272 U.S. 52 (1926) (removal power may not be restricted) with Humphrey's Executor v. United States, 295 U.S. 602 (1935) (removal power may be restricted). Humphrey's Executor is widely viewed as having "constitutionalized" the independent administrative agencies as a "fourth branch" of government, but consideration of their role in the system of checks and balances is beyond the scope of this Article.

103 The Supreme Court has ruled that the legislative veto is generally unconstitutional. See Immigration \& Naturalization Serv. v. Chadha, 103 S. Ct. 2764 (1983) (discussed infra text accompanying notes 194-202); Process Gas Consumers Group v. Consumers' Energy Council, 103 S. Ct. 3556 (1983). A good argument can be made, however, that the legislative veto contained in the War Powers Resolution of 1973, Pub. L. No. 93-148, 87 Stat. 555, is constitutional even after Chadha, because of the unique status of the congressional war power. See Carter, The Constitutionality of the War Powers Resolution, 70 VA. L. Rev. 101 (1984).

104 See A. Schlesinger, supra note 2 (arguing that office of President has grown too strong).

${ }^{105} \AA$ proposal analogous to that which the text disapproves has been made by Professor Calabresi in his Holmes Lectures. See G. Calabresi, A Common LAw for THE AGE of StatuTEs (1982). Somewhat simplified, Calabresi's approach would per- 
of constitutional language are both merely means to the end of maintaining the balance of power among the branches of the federal government.

\section{What What the Court Should Have Said Would Have Meant}

The arguments set out above are arguments that the majority could have made, but failed to make in any detail, in support of the theory that the decision is constitutionally based. The arguments share a simple conclusion: in determining the role that each branch should play in the system of checks and balances, all judgments on proper policy must be subordinated to the most important policy, preserving that selfsame system of checks and balances. Permitting one branch to create fresh remedies will upset the balance. Anything that upsets the balance is wrong. ${ }^{106}$ That is why the federal courts cannot create a cause of

mit "common law courts . . . to treat statutes in precisely the same way that they treat the common law." Id. at 82. "[S]imply living with anachronistic statutes," he writes, "is not really an option." Id. at 110. Calabresi's approach would not violate the Constitution, he explains, because:

[The doctrine of separation of powers] asks us to consider the roles our institutions must play if we are to maintain that balance established by our governmental system. Judicial power to force legislative reconsideration of statutes serves precisely to maintain the balance between the traditional court role of keeping the fabric of the law consistent and up to date and the legislative role of reversing judicial misperceptions of majoritarian demands, while responding quickly to the constitutionally valid needs of special groups. As such it is, in a fundamental sense, fully consistent with the traditional balance of power imposed by our constitutions.

Id. at 116. Calabresi's proposal does indeed ask one branch to use an unusual remedy (Calabresi argues at length that it is not really a "new" one) to shore up perceived deficiencies in the system of checks and balances. As will become clear, however, that does not necessarily make it constitutionally infirm under the theory advanced in the text. Extraordinary necessity might excuse what would otherwise be an arrogation of power. See infra text accompanying notes 134-73. Moreover, Calabresi also suggests that legislative approval (which might be withdrawn at any time) would be necessary before courts could exercise the power he recommends. Id. at 117. Were the legislature expressly to delegate this authority to the courts while retaining political control-the right to renege-then this essay's warnings might not be violated. The principles of separation of powers may also present less of a bar when two branches of government cooperate than when they compete for power. See, e.g., Miller, An Inquiry into the Relevance of the Intentions of the Founding Fathers, With Special Emphasis Upon the Doctrine of Separation of Powers, 27 ARK. L. REv. 583, 589-92 (1973). The question is not easy and this answer remains vague and unsatisfactory.

108 This assertion raises the problem of what to do when something does happen to upset the balance of powers. Suppose one branch of government, as a result of its own misconduct, the lassitude of the other branches, or simple cultural evolution, gradually increases its freedom of action, to the detriment of the other two. If the necessity for fresh remedies proves great enough, a good argument might be made in this narrow circumstance, the principle set forth in text should be altered. Is that an exception so vast that it would engulf the rule? That depends on the way the "necessity" criterion is defined and applied. See infra text accompanying notes 134-73. 
action for damages running against a President or former President on the basis of misconduct in office.

Had it explained Nixon $v$. Fitzgerald that way, the Court would presumably have gone on to explain why the theory that all other interests must be subordinated to the need to preserve the system of checks and balances does not do violence to precedent. A distinction must be drawn between the two very different roles the federal courts play in the system of checks and balances. To paraphrase Felix Frankfurter, when the courts settle a dispute between the two more overtly political branches, they act as "referees at prize fights;" but when they act affirmatively to vindicate an individual claim of right against a representative of another branch, they act as "functionaries of justice."107 In Nixon v. Fitzgerald, an individual asked the Court to make him whole, and the Justices hesitated. The majority's reasoning suggests constitutional limitations on the judicial power to act as functionaries of justice by creating fresh remedies. Nothing in the decision is inconsistent with the cases in which the Court has acted as a referee. ${ }^{108}$

United States $v$. Nixon ${ }^{100}$ does not fall squarely into either category, but it is probably best viewed as a "court-as-referee" decision. The Justices were not settling a dispute between the other two branches, but they were also not protecting the rights of any individual against government excess. The Court was called upon instead to act as referee within a particular branch of government. ${ }^{110}$ The Court ac-

107 Johnson v. United States, 333 U.S. 46, 54 (1948) (Frankfurter, J., dissenting).

108 If the presidential immunity case means that the judiciary is more hesitant to protect individual rights when the Constitution is said to bar relief than it is to intervene in disputes between the other branches of government, one recent proposal on the limits of judicial review is in trouble. Professor Choper suggests that the federal courts should stay out of disputes between the political branches (the Separation Proposal), J. CHOPER, supra note 59, at 263, but ought to act to protect individual rights (the Individual Rights Proposal), id. at 66-68. Part of the problem is that questions of these types are not rigorously separable. Nixon $v$. Fitzgerald raised an individual rights issue with separation of powers implications. The case could be viewed as asking the Court only to make the plaintiff whole, but it could also be viewed as asking the Justices to perform the arguably legislative function of punishing the President. If the case is approached without preconceptions, it is difficult to find a principled reason to argue that the case falls strictly within either the Separation Proposal or the Individual Rights Proposal.

Under the Separation Proposal, moreover, the constitutionality of the legislative veto should have been treated as a nonjusticiable political question. See id. at 357-60. The Court, however, expressly rejected this approach in Immigration \& Naturalization Serv. v. Chadha, 103 S. Ct. 2764, 2779 (1983).

109418 U.S. 683 (1974).

110 Acting as a referee within a particular branch is a power that the Court exercised previously in 1969 when it issued its controversial decision in Powell v. McCormack, 395 U.S. 486 (1969), invalidating a congressional attempt to exclude a member on grounds other than the "Qualifications" that the Court said are set forth expressly 
cepted the task, and its resolution of the dispute required the President to comply with an order. The result in Nixon $v$. Fitzgerald suggests that had the President defied the Court's order in United States $v$. Nixon, the Justices would not have created a fresh remedy through which to try and punish him. ${ }^{111}$ The risk of presidential defiance, however, although much bandied-about at the time, was probably close to nil. President Nixon was politically helpless and the Justices must have known that. ${ }^{112} \mathrm{Had}$ he refused to comply with the Court's "definitive" decision, he would almost certainly have been impeached and removed from office. The federal court could not, under the logic of the presidential immunity decision, have acted against him directly, but a punishment for disobedience would have been imposed all the same. The order would simply have been enforced by a branch other than the one that issued it. ${ }^{113}$

That inability to act against the President directly is hardly inconsistent with other cases in which the federal courts have, in evaluating the legitimacy of presidential actions, evinced reluctance to deal with the President directly. With rare exception, the courts have reviewed presidential activities through suits naming as a defendant not the President himself, but some lower executive functionary. ${ }^{114}$ The same the-

in the Constitution. In Powell, however, the Justices made explicit what was only implicit in United States $v$. Nixon: only the force of the Court's legitimacy stood behind the mandate. Thus, the Court ruled that individual Members of Congress were not proper defendants. Powell, 395 U.S. at 501-06.

12 See supra note 50 and text accompanying notes 42-51. Alternately, perhaps, United States $v$. Nixon need not be harmonized. It may be as Professor Kurland has suggested, that the case was an aberration, "a political decision not a judicial one." Kurland, United States v. Nixon: Who Killed Cock Robin?, 22 UCLA L. REv. 68, 70 (1974). Explaining away hard cases by calling them aberrations is, however, too easy an escape from the need for theory. If the decision can be placed on a principled basis, good; if it cannot, then it was wrongly decided and should be overruled. $C f$. Black, The Lawfulness of the Segregation Decisions, 69 YALE L.J. 421, 421 (1960) (making similar argument with respect to Brown v. Board of Educ., 349 U.S. 294 (1955)).

i12 Nevertheless, the possibility of presidential resistance to the Court's ultimate decree in United States $v$. Nixon was hammered home both in pre-argument White House statements and at oral argument, and the Justices could not have been unaware of the risks. For a discussion of how this awareness might have affected the Court's reasoning in its published opinion, see Mishkin, Great Cases and Soft Law: $\bar{A}$ Comment on United States v. Nixon, 22 UCLA L. REv. 76 (1974). A more speculative, even fanciful, account of the Court's effort to reach a "definitive" decision appears in B. WOODWARD \& S. ARMSTRONG, supra note 32, at 287-347.

${ }^{123}$ In addition to actions taken by Congress, enforcement was also effected in the court of public opinion, where President Nixon had already been tried and convicted. In a sense, as Professors Karst and Horowitz have argued, in turning over the disputed tapes, President Nixon bowed not to the order of the federal courts, but "to political reality." Karst \& Horowitz, supra note 55, at 53.

114 See supra note 3. This explanation may be compared with Professor Freund's comment on the concession by plaintiff's counsel in Marbury v. Madison, 5 U.S. (1 Cranch) 137 (1803), that the President might not be a proper subject of mandamus. 
ory-that no punishment question was involved and the courts were merely acting as referees-may explain these results, but another theory fits them even better. The President was not a defendant, and it is only to the President himself, with his special place in the constitutional scheme and history, that immunity attaches. ${ }^{115}$ The Supreme Court acknowledged as much when, on the same day that it decided the presidential immunity case, it ruled in Harlow $v$. Fitzgerald that no similar immunity attaches to the President's aides. ${ }^{116}$ Because the President almost always acts through his subordinates, a non-immune de-

Wrote Freund: "This concession could be readily made, however, because a practical alternative existed - the President's subordinate could stand in judgment." Freund, The Supreme Court, 1973 Term-Foreword: On Presidential Privilege, 88 HARv. L. REv. 13,19 (1974). Freund went on to suggest that this alternative was not present in United States v. Nixon:

If members of Congress cannot be sued for their official conduct, still officers of their house may be answerable for carrying out those actions, as cabinet officers may be legally accountable for executing presidential directions. This time-honored means of accommodation was made unavailable in the tapes case by the President's action in formally taking sole custody of the tapes. Thus the usual suit against a subordinate became impossible, and a confrontation was compelled.

Id. at 19-20 (footnotes omitted).

${ }_{116}$ Thus, in Socialist Workers Party v. Attorney General, 596 F.2d 58 (2d Cir. 1979), the Court of Appeals ruled that although a contempt citation against the Attorney General was improper in the case sub judice, such a citation might be appropriate in some other case. The court noted that "the executive responsibilities and constitutional status of the Attorney General do not compare to those of the President," $i d$. at 62, but added:

Although we unequivocally affirm the principle that no person is above the law, ... . we cannot ignore the fact that a contempt sanction imposed on the Attorney General in his official capacity has greater public importance, with separation of power overtones, and warrants more sensitive judicial scrutiny than such a sanction imposed on an ordinary litigant.

Id. at 64. The panel concluded that "holding the Attorney General of the United States in contempt to ensure compliance with a court order should be a last resort, to be undertaken only after all other means to achieve the ends legitimately sought by the court have been exhausted," id. at 65 , and vacated the district court's contempt order pending the application of less intrusive sanctions. The implication of the court's opinion, however, is clearly that contempt is available against the Attorney General.

A district court in California recently applied a lesser sanction, dismissing a criminal prosecution at least in part because of the government's refusal to comply with an order requiring Presidential Counselor Edwin Meese to appear and testify. See United States v. Wayte, 549 F. Supp. 1376 (C.D. Cal. 1982). Dismissal was less intrusive than contempt because dismissal merely ended the judicial role; it did not force any executive official to do anything. Dismissal was not an available sanction in the case giving rise to the Second Circuit's opinion, because that case was a civil suit against the United States. The analogous sanction would be a default judgment against the government.

The distinction between the President and his aides for immunity purposes is further discussed infra notes 124-52 and accompanying text.

116 See Harlow v. Fitzgerald, 457 U.S. 800 (1982) (discussed infra, text accompanying notes $124-41$ ). 
fendant will generally be available in any case brought to contest the validity of a presidential directive. ${ }^{117}$

If the President's aides are not immune from suit as he is, they may be placed in an uncomfortable position when he orders them to do something that they believe to be wrong. There is a temptation to say flippantly that an executive functionary placed in that position may resign, tell his story to the Washington Post, and write a bestselling book. More seriously, the position may be uncomfortable, but the choice should not be difficult. The employees of the executive branch work for the United States of America, not for the person who happens to occupy the office of President. Faced with an order they believe to be illegitimate, executive functionaries should state their belief and refuse to carry the order out. They may be dismissed for that refusal, but they will have acted in accord with the requirements of the Constitution.118

Just as nothing in the presidential immunity decision is inconsistent with the courts' acting as a functionary of justice in cases involving non-immune defendants, nothing about the ruling suggests a judicial inclination to stop acting as referee in many disputes between the President and the Congress. A federal court does not create a forbidden fresh remedy for misconduct merely because it decides such cases as Myers, ${ }^{\mathbf{1 1 9}}$

117 See Professor Freund's comment quoted supra note 114 . In his dissent in Harlow v. Fitzgerald, 457 U.S. 800, 822-29 (1982), Chief Justice Burger argued that the Court's refusal to grant absolute immunity to the President's aides, on a theory deriving their immunity directly from the President's own, is inconsistent with earlier decisions permitting legislative aides to partake derivatively of legislator's immunity. See Doe v. McMillan, 412 U.S. 306 (1973); Gravel v. United States, 408 U.S. 606 (1972). The legislative immunity cases need not, however, be read beyond their facts: those cases may have decided that, in the particular circumstances presented, congressional aides were immune as a matter of law. They need not be read as saying that congressional aides are always immune. Cf. Powell v. McCormack, 395 U.S. 486 (1969) (permitting suit against congressional employees while dismissing members of Congress as defendants). Even if Harlow $v$. Fitzgerald cannot be harmonized with the cases on immunity of congressional employees, that does not compel the conclusion that Harlow v. Fitzgerald was wrongly decided. Perhaps McMillan and Gravel are the cases that were wrongly decided.

118 At that point, the dismissed employee might try to sue for backpay. The next employee up the line might be the proper subject of suit, and so on, until the Oval Office is reached. The President, of course, would be immune, which might mean that someone would be without remedy. Whether the plaintiff would really have to go home emptyhanded is less than clear, though, because (1) another official, perhaps an official in charge of signing paychecks or filing personnel records, might be brought in as a defendant, and (2) faced with this enormous rebellion among executive branch employees, the President, as a practical matter, would surely cave in. If, on the other hand, someone is indeed left without a remedy, that would not necessarily represent a failure within the system. See infra note 209.

110 Myers v. United States, 272 U.S. 52 (1926) (provision requiring Senate consent to removal of postmasters held unconstitutional). 
Humphrey's Executor, ${ }^{120}$ Nixon v. Administrator of General Services, ${ }^{121}$ and Chadha: ${ }^{122}$ whether a forbidden remedy is created depends on the result that is reached. By engaging in judicial review, the courts are only doing what they have always done: acting as referees and determining the constitutionality of what the other branches are doing. Deciding cases does not upset the balance of powers but reaching the wrong decision may. In each case, the primary consideration must be the preservation of the system of checks and balances. Unless the Justices are prepared to hold that Congress has broader discretion to formulate new remedies than the Court does (a proposition not impossible to support), ${ }^{123}$ the Justices should rule against the validity of the new remedies that Congress creates.

\section{Refining the Theory: Some Political Aspects of Judicial Power}

If the presidential immunity decision has any constitutional basis, its theory is probably that the federal courts may not punish the President of the United States for misconduct. Although the majority based its conclusion primarily on "public policy," the decision finds more solid support in the history and structure of the system of checks and balance. The time has come, then, to treat some rather obvious objections to this theory that the system of checks and balances prohibits judicial creation of new remedies against the President, objections that although unmentioned in the previous pages, must surely have been burning in the reader's mind. If the federal courts can never create new remedies then what have they been doing all these years with injunctions and damages against other executive officials? Would the theory really require the remarkable conclusion that the courts must stop? If the federal courts really cannot punish the President, can they really be said to have the power to "command" him to act? If Congress alone may punish the President, then what has the system as a whole to say to an individual wronged by presidential action? These objections are strong, but the theory developed in the preceding sections, with only minor modifications, can handle them.

120 Humphrey's Executor v. United States, 295 U.S. 602 (1935) (upholding provision limiting President's power to remove commissioner of independent agency).

121433 U.S. 425 (1977) (upholding restrictions on President's ability to dispose of his personal papers). This case is discussed in greater detail supra text accompanying notes 37-39.

122 Immigration and Naturalization Serv. v. Chadha, 103 S. Ct. 2764 (1983). The case is discussed infra text accompanying notes 194-202.

${ }^{123}$ See supra text accompanying notes 34-39. 


\section{A. Relaxing the Rule: A Proposal for a Judicial "Necessary and Proper" Clause}

The Supreme Court has never adhered to the theory that the Constitution prohibits the judiciary from providing any remedy against the executive or legislative branches not expressly authorized by the Constitution. If it did so, much of the accepted machinery of judicial review would suddenly be rendered inoperable. Thus, on the same day that it decided the presidential immunity case, the Supreme Court ruled in Harlow $v$. Fitzgerald ${ }^{\mathbf{1 2 4}}$ that the rule against implying a cause of action for civil damages in cases of presidential misconduct would not apply ipso facto to suits against the President's aides. Their liability or immunity would be judged instead under the standards set forth in Butz $v$. Economou, ${ }^{125}$ in which the Court held for the first time that high-ranking federal officials might, in certain cases, be ordered to pay damages to individuals injured by the officials' abuse of power. ${ }^{126}$ The federal courts, moreover, have frequently issued orders commanding lower federal officers to act in one way or refrain from acting in another. Yet the Constitution nowhere grants the courts the explicit authority to issue orders in these areas. Are these, then, forbidden new remedies?

Perhaps this puzzle lends support to the suggestion made earlier that Nixon v. Fitzgerald was a federal common law decision and not a constitutional one. Even if the case is viewed as having established a constitutional rule, however, the presidential immunity decision need not be read as inconsistent with "executive review" of the kind in which federal courts routinely engage.

In the first place, lower officials are not the President. This distinction is crucial if part of the reason for the immunity rule is the unique status of the President in the structure of government. All the executive authority is vested in the President. ${ }^{127}$ Other officials exercise only as much of it as the President permits, and they are always subject to his direction. ${ }^{128}$ It is the President who stands for election after four

124457 U.S. 800 (1982).

125438 U.S. 478 (1978).

128 Economou was not, however, the first Supreme Court case to infer a private cause of action against a federal official for constitutional violations. See Bivens v. Six Unknown Agents, 403 U.S. 388 (1971). The distinction is that Bivens involved relatively low-level personnel not expected to exercise broad discretion, whereas Economou permitted a suit against a cabinet official who, as such, was granted enormous discretion.

127 U.S. ConST. art. II, §1.

128 The assertion that executive officials act only under the President's direction should not be taken to imply that, as a practical matter, the President can possibly know everything that is going on-or even a substantial portion of what is going on-in the executive branch. He can, however, find out (if he wants to) what any 
years, ${ }^{129}$ and it is the President against whom most of the political fire-from Congress, from the press, and from the public-will ultimately be directed. ${ }^{130}$ That says a great deal, but it does not say everything. Lower federal officials, after all, can be hired and fired, and even impeached and removed from office by Congress. So the Constitution includes some very specific checks on the lower officials and their power. How, then, can the federal courts create new ones?

One answer may be that the Framers thought that the general grant of "the judicial Power of the United States" to courts created by Congress under Article III included a grant of power to formulate proper remedies for misconduct. ${ }^{131}$ A better answer may be that "judicial Power" must mean something, and the term might reasonably be read to imply a general remedial power. ${ }^{132}$ Another and still better an-

particular agency or official is doing and may, within the bounds of the law, direct that agency or official to do otherwise.

129 The Framers apparently considered four years a rather short term of office, and not nearly enough time for the President to do very many evil things. See 2 RECORDS, supra note 75, at 524 (A. Hamilton) (President elected for four years preferable to "a monster elected for seven years"). The general idea was to keep the term short enough so that the public could depose a President who did wrong. Today, some propose that the President be limited to a single, six-year term. In fact, because decisions can now be implemented so swiftly, the Framers' concerns would be better served by shortening the President's term.

130 Thus, bad policymaking in the executive branch is frequently blamed on the President and not his aides. That attitude makes systemic sense: the President is vested with the entirety of the executive power, and it is perfectly legitimate to hold him responsible for his delegations of authority.

1s1 There is little disagreement that the Framers expected the federal courts to possess some inherent power to create appropriate remedies, even against the government itself. See, e.g., The Federalist No. 78 (A. Hamilton); P. SchUcK, supra note 29; G. Woon, supra note 71 . The concept of judicial review may be viewed as a mere variation on traditional equity power. Even the opponents of a broad inherent remedial power concede that some equitable authority was intended. See, e.g., G. MCDowELl, EQUTTY AND THE CONSTITUTION (1982). Interesting treatments of the historical views on the inherent equitable powers of the federal courts appear in two articles by Robert von Mischzisker, Equity Jurisdiction in the Federal Courts, 75 U. PA. L. REv. 287 (1927), and Mischzisker, The Common Law and Our Federal Jurisprudence, 74 U. PA. L. Rev. 109 (1925).

132 Article III defines the "judicial Power of the United States" as "extend[ing] to all Cases, in Law and Equity, arising under this Constitution [and] the Laws of the United States." U.S. CoNSr. art. III, \& 2 (emphasis added). This phrase cannot easily be construed to mean that the selection of remedies is left entirely to some other body, such as Congress. See Dellinger, Of Rights and Remedies: The Constitution as Sword, 85 HaRv. L. REv. 1532, 1540-43 (1972). The federal courts have broadened their willingness to exercise inherent equitable powers to the point where innovative remedies have become the order of the day. See, e.g., O. Fiss, The Civil Rights InjuncTION (1978); Hill, Constitutional Remedies, 69 Colum. L. REv. 1109 (1969). This development is not, of course, without its critics. See, e.g., G. McDowell, supra note 131 (expansion of remedies mistakes meaning of equitable power); Nagel, Separation of Powers and the Scope of Federal Equitable Remedies, 30 STAN. L. REv. 661 (1978) (doctrine of separation of powers limits equitable power); Van Alstyne, supra note 33 
swer is that the Constitution leaves the organization of the federal courts to Congress, and Congress, relying on its express powers and the Necessary and Proper Clause, has granted to the federal courts the authority to issue appropriate remedies in particular cases. ${ }^{133}$

Although each of the answers has some merit, they do not-either singly or together-suffice. Each supports the conclusion that the federal courts are empowered to create new remedies for misconduct in appropriate cases. That authority, however, cannot be infinite, and none of the answers set out above can explain rationally where the limits lie. The "public policy" analyses made by the Court in the two Fitzgerald cases may supply a basis for delineating those limits.

In Nixon v. Fitzgerald, Justice Powell wrote for the majority that in weighing the former President's claim to immunity, the Court must determine whether "judicial action is needed to serve broad public interests."134 That statement might be written off as a mere assertion of what is "good" or "bad," not related to the structure, text, or history of the Constitution. ${ }^{135}$ If, however, the majority intended to state a constitutional rule, then this comment about necessity should be examined in more detail. The opinion gave as an example of the kind of "necessity" that might justify judicial action, intervention "not in derogation of the separation of powers, but to maintain their proper balance."136 The majority cited Youngstown Sheet $\mathcal{E}^{2}$ Tube Co. v. Sawyer ${ }^{137}$ as an instance in which this type of intervention had been necessary. In Youngstown, the powers of government were thought to have been thrown out of balance by the executive branch's attempt to undertake what the Court insisted was a legislative responsibility. ${ }^{138}$ Presumably,

(judicial selection of remedies is narrowly circumscribed absent congressional authorization).

${ }^{133}$ Cf. Dellinger, supra note 132, at 1543-52 (discussing ways of harmonizing judicial and congressional authority to create remedies for constitutional violations); Wechsler, Federal Jurisdiction and the Revision of the Judicial Code, 13 LAw \& CoNTEMP. PROBS. 216, 225, 241 (1948) (recommending legislation channeling judicial discretion to imply private rights of action).

1s4 457 U.S. 731, 754 (1982) (emphasis added).

135 See supra text accompanying notes 16-26.

136 Nixon v. Fitzgerald, 457 U.S. at 754.

157343 U.S. 579 (1952) (the Steel Seizure Case).

138 In Youngstown, the Court acted at the behest not of Congress, but of the owners of the steel mills that the President had seized without legislative authorization. So although the Justices arguably were called upon to act in order to preserve the separation of powers, the fact remains that Congress was not complaining about any presidential arrogation of legislative responsibilities.

Professor Choper, in his Separation Proposal, see supra notes 59 \& 108, suggests that the Court should have held the issues presented by Youngstown nonjusticiable, because the mill owners were not claiming a right to be free of any government seizure of the mills, but only of a seizure without congressional authorization. J. CHOPER, 
the Nixon $v$. Fitzgerald majority believed that only judicial action could rectify the imbalance-a view that may or may not have been correct. The citation to Youngstown may give some indication of the kind of imbalance the Nixon $v$. Fitzgerald majority had in mind. In Nixon $v$. Fitzgerald the Court could find no necessity sufficient to justify judicial intervention; the existing balance of powers was adequate.

In Harlow v. Fitzgerald, however, Justice Powell's majority opinion said something very different. "In situations of abuse of office," he wrote, "an action for damages may offer the only realistic avenue for vindication of constitutional guarantees."139 Thus the Court concluded that the misbehavior of presidential aides-unlike the misbehavior of the President himself - may necessitate judicial intervention. Because intervention may sometimes be necessary, formulating a rule granting aides absolute immunity would be inappropriate. Instead, the aides are immune only "insofar as their conduct does not violate clearly established statutory or constitutional rights of which a reasonable person would have known."140

The question whether the Court's conclusion in Harlow v. Fitzgerald is right or wrong can be put aside for the moment. More important at this point is the standard that the majority applied. The criterion that distinguished Harlow $v$. Fitzgerald from Nixon $v$. Fitzgerald in the minds of the Justices was the necessity for judicial action. In the

supra note 59, at 271-72. The underlying premise of Choper's argument is that in a case such as Youngstown, individual litigants are essentially asserting what might be called "Congress's rights" rather than their own. The difficulty with this premise is that it assumes that the only reason that the governmental structure has been created the way it has is in order to protect the institutions of government from one another. The desire to protect the branches from each other is one reason-but the less important one-that the government is structured as it is. Far more important is the need to create a particular legal and political process for the protection of citizens. The system of checks and balances is not an end in itself, but a means to an end. When a citizen is deprived of something and the system of checks and balances-that means to an end-has been ignored, that individual has a colorable claim that he was denied due process.

The thesis presented in this Article-that the working of the system of checks and balances is mostly political-is certainly one that underlies Professor Choper's Separation Proposal, but the thesis presented here would not require that the courts play so narrow a role as Choper would prescribe.

139 Harlow v. Fitzgerald, 457 U.S. at 814. Actions for damages against the Crown's ministers were recognized at common law. For an explanation of the evolution and operation of this process, see P. ScHUck, supra note 29, at 30-35. See also supra note 114 (Watergate tapes case as analogous) and infra note 215 (views of Framers).

${ }^{140}$ Harlow v. Fitzgerald, 457 U.S. at 818. This so-called "objective" standard is supposed to protect government officials from unnecessary interference with their duties by permitting frivolous suits to be dismissed on the pleadings, but it is questionable whether the standard really has the intended effect. See P. ScHuCK, supra note 29, at 68-79, 87-99. 
one case, the Court reasoned, implied civil damages liability was necessary; in the other, it was not. Similarly, the subpoena approved by the Court in United States $v$. Nixon may have been necessary in a way that an ordinary injunction against the President is not. ${ }^{141}$ In ordering the President to turn over the Watergate tapes, the Justices must have believed that inaction on their part would do violence to the system of checks and balances and that action was therefore essential. A similar premise must underlie the Court's decision in Harlow v. Fitzgerald. That premise may be true or false, ${ }^{142}$ but it is certainly consistent with the reasoning used by the majority in Nixon $v$. Fitzgerald. For while the Court recognizes that there might sometimes be a need to hold lower executive officials to liability in damages, the Court takes the view that the need for imposing that punishment-that check-on the President has not been demonstrated. ${ }^{143}$ That is why the Court could reach different results in the two Fitzgerald cases and yet justify each as a matter of constitutional power rather than of judicial prudence.

On this view, the constitutional grant of "the judicial Power" becomes a kind of judicial "necessary and proper" clause with respect to the creation of remedies for wrongs arising under the Constitution and the laws of the United States. ${ }^{144}$ If this theory is correct, the fede ${ }^{-1}$ courts may indeed establish fresh remedies-remedies not called for $t$, the Constitution-but not in every case. They may do so only when the new remedies are necessary and proper. 114.

141 Certainly that is the thrust of Professor Freund's comment quoted supra note

142 The Chief Justice, alone in dissent in Harlow v. Fitzgerald, argued vigorously that the premise is false. See Harlow v. Fitzgerald, 457 U.S. at 822-24. The question whether the case's result is correct is discussed in brief infra, text accompanying notes 217-19.

143 For reasons that will shortly become clear, what matters is not whether judicial intervention is "necessary" in order to protect individual rights, but whether it is "necessary" to ensure adequate checks on misconduct. Nixon v. Fitzgerald and Harlow $v$. Fitzgerald are harmonized if one accepts the proposition that adequate checks exist on the President but not on his assistants. See also infra text accompanying notes 21617.

144 This idea is intimated in J. I. Case v. Borak, 377 U.S. 426, 433 (1964), in which the Court suggests that implication of a private right of action might turn on the "necessity" or "appropriateness" of that remedy. See also Bivens v. Six Unknown Agents, 403 U.S. 388, 402-11 (1971) (Harlan, J., concurring in the judgment). Professor Dellinger and Professor Van Alstyne have both suggested that the equitable powers of the federal courts might authorize them to create those remedies that are "essential" or "indispensable." See Dellinger, supra note 132, at 1547-52; Van Alstyne, supra note 33, at 796-98. Dellinger also considers the Borak language quoted earlier in this footnote, but he concludes that the proper inquiry is whether the remedy is necessary to guarantee individual rights, not whether it is necessary to ensure the continuing balance of powers. Dellinger, supra note 132, at 1550-51. 
Like the Article I necessary and proper clause, ${ }^{145}$ the Article III grant of judicial power would have its limits. The Article I clause permits Congress to enact laws that are necessary and proper to further some particular national power. Since the time of McCulloch v. Maryland, ${ }^{148}$ it has been clear that the Clause presents no formidable barriers to legislative activity. As Chief Justice Marshall pointed out in $M c$ Culloch, the Article I necessary and proper clause is a grant of power, not a limitation on its use. ${ }^{147}$ The terms of the clause have always been read broadly. The concept of "necessary" has never been taken to require "absolute necessity"; some sort of reasonable relationship between ends and means has been sufficient. ${ }^{148}$ The word "proper" has been read to mean "appropriate," which adds little to "necessary," except for a strong implication that legislation is appropriate only when it does not conflict with another constitutional provision. ${ }^{149}$

So it could be with Article III's grant of judicial power. In formulating fresh remedies for misconduct by the other branches of government, the judiciary would have to act with like constraints in mind. The remedies created under Article III must bear a reasonable relation to the wrong-in other words, they must be a good idea-and they must also be consistent with the other provisions of the Constitution.

Deciding whether a remedy is a good idea is a task that has, since equity took form many centuries ago, been left to the wisdom of the court. The problem of assuring the constitutionality of a fresh remedy is also for the court in the first instance, but it is important to search for limiting standards.

One possible limiting standard derives from the separation of powers, which might require the courts to impose the least intrusive among arguably necessary remedies. For example, it can be argued that neither an award of damages nor a prohibitory injunction is as intrusive into the affairs of another branch as is a structural injunction. ${ }^{150}$ If

145 U.S. ConsT. art. I, § 8: "The Congress shall have Power . . . To make all Laws which shall be necessary and proper for carrying into Execution the . . . [enumerated] Powers, and all other Powers vested by this Constitution in the Government of the United States, or in any Department or Officer thereof."

14817 U.S. (4 Wheat.) 316 (1819).

147 Id. at 413-21.

148 The classic formulation of this doctrine is Marshall's statement in McCulloch: "Let the end be legitimate, let it be within the scope of the constitution, and all means which are appropriate, which are plainly adapted to that end, which are not prohibited, but consist with the letter and spirit of the Constitution, are constitutional." Id. at 421 .

148 See L. TRIBE, supra note 64 , at 228.

150 See P. Schuck, supra note 29, at 14. As Professor Schuck demonstrates, however, an award of damages can be more intrusive than anything else. Forcing an official to pay money from his own pocket may chill the official's willingness to exercise discretion. See id. at 68-81. In traditional separation of powers analysis, the degree of intru- 
that is the case, the court should be quicker to award one of the former remedies against an executive functionary. ${ }^{151}$ On the other hand, to the extent that an award of damages is viewed as punishment for wrongdoing, ${ }^{162}$ the court should be reluctant to impose the award at all (especially upon the President), because the system of checks and balances plainly leaves punishment of the President to political actors other than the courts.

Another way of ensuring the constitutionality of a fresh remedy would be to make the standard for "necessity" somewhat higher under Article III than it is under Article I. If the federal courts essentially serve as referees in the game of checks and balances, then they ought to follow the suggestion in the majority opinion in Nixon $v$. Fitzgerald and hold that the only necessity that matters is the necessity to preserve the system. ${ }^{163}$ "Necessity" would then be an indispensable ${ }^{164}$ but not sufficient condition for the creation of a fresh remedy. ${ }^{165}$

Raising the necessity barrier also makes systemic sense. As a general rule, the powers granted to Congress are plenary. Although it may

siveness is critical. See, e.g., Nixon v. Administrator of Gen. Servs., 433 U.S. 425 (1977); Buckley v. Valeo, 424 U.S. 1 (1976).

151 In practice, injunctions are awarded against federal officials more often than are damages. The injunctions awarded, however, are usually mandatory or prohibitory injunctions; structural injunctions against coordinate branches of the federal government are, as they should be, exceedingly rare.

182 The idea that an award of damages is punishment makes a good deal of sense if one considers the vantage point of the defendant, who is unlikely to see an award of damages as anything else. In addition, an award of damages, unlike an injunction, looks mostly to past rather than to future conduct, and thus again resembles punishment. See Whitman, Constitutional Torts, 79 MicH. L. Rev. 5, 53 (1980). The mere fact that an award of damages looks to future conduct in the sense of (possibly) deterring it, does not change the status of damages as punishment for the individual defendant.

183 A form of this argument has been used to defend a broad inherent judicial review function that Congress cannot limit through use of the "exceptions" clause. The federal courts, some say, must have whatever jurisdiction is "necessary" to vindicate the balance of powers. See, e.g., Sager, The Supreme Court, 1980 Term-Foreword: Constitutional Limitations on Congress' Authority to Regulate the Jurisdiction of the Federal Courts, 95 HaRv. L. Rev. 17 (1981) (Supreme Court may use inherent power to restore balance of powers by striking down "court-stripping" legislation); see also Eisenberg, Congressional Authority to Restrict Lower Federal Court Jurisdiction, 83 YALE L.J. 498 (1974) (federal courts must have adequate jurisdiction to play constitutional role).

184 This is not to suggest that all "court-as-referee" cases ought to be viewed as instances of constitutional crisis, but rather that when asked to intervene in a dispute between two branches, the Court should have the preservation of the system as its prime concern.

153 At the risk of trivializing the argument, it is worth pointing out that among other requirements, until the appropriate case arises, the courts cannot create a fresh remedy, no matter how great the necessity. This distinction between the judicial power to act out of necessity and the legislative power to do the same is crucial to a proper understanding of the system of checks and balances. 
not, of course, legislate in violation of the Constitution, the legislative branch is in the strongest position to be innovative and creative. The federal courts, on the other hand, are merely reactive-they resolve only controversies brought before them but cannot make law on their own initiative-so they have less opportunity to exercise creativity. As long as the courts follow Nixon $v$. Fitzgerald and impose only the least intrusive remedy needed to preserve the balance of powers, they will be acting in conformance with the mandates of the Constitution. ${ }^{156}$

Assuming that Congress either does not possess or, in the end, chooses not to exercise a power to strip the Supreme Court of jurisdiction over specific categories of constitutional cases, the only checks on the judicial creation of new remedies will be those imposed through the political process. Checks of this kind, while carrying considerable force, are imposed in a manner that is essentially standardless. Some of the checks are the traditional ones. The size of the Court may be altered, new justices may be appointed, the Court's budget may be slashed, ${ }^{157}$ and so on. Even adverse public opinion, when it grows to the point of threatening the widespread acceptance of the Court's legitimacy, plays a role. ${ }^{158}$ The major check, however, is the most practical one, selfimposed to avoid an external threat: the realization that other branches of the federal government may refuse to comply with the courts' dictates.

Suppose for example, that the Supreme Court, in a burst of foolishness were to declare that because the President deserved impeachment, and Congress had failed to act, the Constitution required that the President be suspended from office until Congress did its duty, or re-

158 The courts have available other "remedies" for misconduct that are considerably less extraordinary. For example, the Supreme Court has laid down a rule that statutes should be construed so as to avoid any constitutional problems. See, e.g., NLRB v. Catholic Bishop of Chicago, 440 U.S. 490 (1979); Kent v. Dulles, 357 U.S. 116 (1958). This rule is obviously a means by which the Court can "outlaw" behavior it finds objectionable without reaching the issue whether the behavior actually violates the Constitution.

157 If the Justices are determined to rule in a particular way, budget-cutting should have little effect. Their salaries cannot be diminished, U.S. CoNST. art. III, $\S 1$, and although their staff support may shrink, and they may even lose their building and their print shop, they can continue to issue their opinions, even if they must scribble them on cardboard found in the street. I am indebted to Guido Calabresi for pointing out to me the ability of the Justices to resist this particular form of pressure.

${ }^{158}$ It is far too late in the day to claim the courts are completely insulated from public opinion, as Hamilton said they would be, see The Federalist No. 78, at 490 (A. Hamilton) (B. Wright ed. 1961), but studies of the judicial response to public opinion do suggest that "[f]alling support does not produce the automatic alterations in policy output in the federal judicial system to the extent that occurs with other social and political systems," S. Goldman \& T. Jahnige, The Federal Courts as a Political System 148 (1971). 
quired that the Court command Congress to impeach and convict. The Court might justify these orders as necessary to restore the balance of power between the executive and legislative branches. Sheer nonsense? Something that would never happen? Perhaps. And it may be true, as John Ely has remarked, that "it can only deform our constitutional jurisprudence to tailor it to laws that couldn't be enacted,"158 or presumably, to decisions that could never be handed down. Still, the Justices have done some peculiar things over the past two centuries, ${ }^{160}$ and there is time for them to do a few more before the millenium. So, it might be wise, at least for the sake of discussion, to take seriously the possibility that the Court would act irresponsibly.

If the Court did order the President suspended, creating an action suspendatur per necessitas as it were, ${ }^{161}$ the President would certainly refuse to leave, and it is unlikely (although anything is possible) that the House would then impeach him for failure to comply with the definitive order of the Supreme Court. Similarly, if the Court ordered the House to begin impeachment proceedings against the President, the Justices might be surprised to learn the identities of those finally named in the bill of impeachment. In short, by attempting to create these remedies, the Court would risk the precious aura of legitimacy that feeds its authority. That the Justices are unlikely to do.

That conclusion includes both descriptive and prescriptive elements. It describes the way judges actually behave. Judges do hesitate to issue orders when there is doubt as to whether the orders will be obeyed. ${ }^{162}$ The Supreme Court has more than once expressed concern over the possibility that a decree running against a co-equal branch of the United States government might be ignored. ${ }^{163}$ The judicial ten-

$159 \mathrm{~J}$. ELY, supra note 64, at 183.

160 See, e.g., Korematsu v. United States, 323 U.S. 214 (1944) (racially-defined exclusion of American citizens approved); Bradwell v. Illinois, 83 U.S. (16 Wall.) 130 (1873) (Bradley, J., concurring) (woman's place is in the home); Dred Scott v. Sandford, 60 U.S. (19 How.) 393 (1857) (black persons held inferior to others).

${ }_{161}$ This irresistible but atrocious pun does literally mean what it appears to mean, "suspended by necessity," but the word "suspendatur" refers to the kind of suspension that occurs when one is hanged by the neck. Still, presidential suspension would, like hanging, be a form of punishment.

${ }^{162}$ For a discussion of this problem, see, e.g., Fiss, The Supreme Court, 1978 Tern-Foreword: The Forms of Justice, 93 HARv. L. REv. 1, $54-55$ (1979).

163 See, e.g., Mississippi v. Johnson, 71 U.S. (4 Wall.) 475, 500-01 (1867); Chisholm v. Georgia, 2 U.S. (2 Dall.) 419,478 (1793). In the twentieth century, the Supreme Court has managed to temper this fear because it has mustered powerful public support for its institutional legitimacy. See infra note 170. Nevertheless, President Nixon's potential defiance may have been one of the elements underlying the Court's strongly-worded opinion in United States $v$. Nixon, see supra note 112, and future defiance, especially in this era of political assault on the Court's legitimacy, is hardly out of the question. 
dency to try to conserve what it and others see as precious "constitutional capital" is frequently lauded, ${ }^{\mathbf{1 8 4}}$ but this same tendency is sometimes criticized as well for being taken too far. ${ }^{168}$

The prescriptive element is somewhat more complex. Certainly a judge should not refuse to award the remedy that justice demands merely because official defiance is possible. The practice that Professor Fiss has labeled "tailoring the right to fit the remedy"168 smacks more of judicial fearfulness and submissiveness than of judicial courage or prudence. There is something to be said for doing the right thing, and if more of a motivation is needed, the judge may always hope for vindication by history. ${ }^{107}$ But the judge must strike a delicate balance. The fact that another branch of government is well positioned to ignore the order ought to give her pause. Perhaps there are strong structural reasons counseling against intervention by the judiciary. Perhaps the constitutional system commits decision elsewhere. Perhaps the question involves one of what Justice Frankfurter called "those decencies of conduct which should control the other branches of government but are without judicial sanction."168 The courts, in short, cannot do everything. When the political structure makes disobedience both likely and constitutionally defensible,${ }^{169}$ the courts are probably straying very close to one of those things that they should not do. Ordering the President to quit or the Congress to impeach would surely be among those things: the structure of the system makes defiance both easy and likely. So the objection is well-taken. The hypothetical would never occur as a practical matter. Thus, a judicial "necessary and proper" clause

164 See, e.g., A. BiCKEL, supra note 69, at 111-98; J. CHOPER, supra note 59, at 140-50. Scholars sometimes assert that public resistance to judicial decrees can even serve a kind of "educational function" for the Justices. See, e.g., A. Bickel, THE MoRALITY OF CONSENT 94-126 (1975) (interaction between court and other institutions) [hereinafter cited as A. BICKEL, MoRALITY]; Wellington, The Nature of Judicial Review, 91 YALE L.J. 486, 516 (1982) ("it is a wise court that pays attention to the community-not out of fear, but out of obligation"; "When the Court recognizes that it has made a mistake, it should, in the appropriate case, rectify the situation").

1es See, e.g., Karst \& Horowitz, supra note 55, at 53 (criticizing Court's tendency to "sh[y] away from political confrontations it might lose"); Rostow, The Japanese American Cases-A Disaster, 54 YaLE L.J. 489, 515-16 (1945) (attacking "blind deference" to expertise).

${ }^{168}$ Fiss, supra note 162, at 55.

${ }^{167}$ See, e.g., R. Kluger, Simple JuStice 715 (1976) (extolling as "Iuminous" the first Justice Harlan's dissent in Plessy v. Ferguson, 163 U.S. 537 (1896)).

${ }^{168}$ Frankfurter, John Marshall and the Judicial Function, 69 HARv. L. REv. 217, 235 n.2 (1955).

188 "Constitutionally defensible" should be taken only to mean that a branch of government choosing to defy the order would have a colorable argument deriving from constitutional structure. The dispute ultimately would be settled in the public arena, so it does not really matter who is "right," in the sense of being able to set forth a more impressive list of authorities. 
would limit the types of new remedies that could be created and would not be a general license for the willy-nilly imposition of extraordinary demands on other branches for the simple reason that if the demands were ridiculous, the Congress and the President would ignore them. ${ }^{170}$

Givil damages for presidential misconduct are obviously in a different category. A sitting President ordered by the courts to pay money damages would probably-although not certainly-pay up. Had one vote shifted in Nixon v. Fitzgerald, a former President would have faced a civil trial. Had the lower court found the former President liable, he would have paid its judgment or suffered the consequences, like any other litigant. ${ }^{171}$ That result would not have been either ridiculous or irresponsible. The Court could, however, sanely conclude that that result was not necessary. Sufficient checks on presidential misconduct already exist. The Nixon resignation (so the Justices might have reasoned) adequately illustrates the point. So the system of checks and balances is in good working order. ${ }^{172}$ Given that the system is functioning

170 The coin has another side, and this principle, too, will only limit the Court so much. The ability of the other branches to govern is closely tied to a public perception that their rule is in accordance with law. They therefore have an incentive not to disobey too frequently the decisions of the federal courts. As one of my students has recently put it, "[o]ver the years the Supreme Court has so clearly defined its role as supreme interpreter of the Constitution and has so closely linked itself to the fundamental law of the nation that a loss of prestige for the Court is a loss for the Constitution as well." E. Shadur, The Nature of Judicial Review 6 (Oct. 1982) (unpublished essay). Similarly, one branch will have difficulty withstanding a court order if the other branch-or the voting public-wants the order enforced. Professor Wechsler has put the matter simply:

[T] here are political limits on the Supreme Court's authority to bind the other branches and the States by its interpretation of the Constitution but ... such limits are not reached without a national consensus shared by both the President and Congress. Protest having less support cannot prevail in the long run unless, perchance, it moves the Court itself to a reversal of position.

Wechsler, The Courts and the Constitution, 65 CoLum. L. REv. 1001, 1009 (1965). None of this should be taken as an endorsement of what Judge Wyzanski once called the view of a "self-depreciatory skeptical seer" (Learned Hand), that "all depends upon the mood and habits of a people; courts amount to little; and the doctrines of constitutionalism constitute not law but the sort of myth which has as its chief worth the encouragement of a continuity of customary habits and a spirit of moderation." Wyzanski, Constitutionalism: Limitation and Affirmation, in GoverNMENT UNDER LAW 473, 485 (A. Sutherland ed. 1956). As should be apparent from the text, this author's view is that the system may be the problem or it may be the solution, but it undeniably exists.

171 Unlike a sitting President, a former President is guarded by only a rather small Secret Service contingent and commands no armed forces. Consequently, a team of federal marshals could probably bring him to justice after a short battle.

${ }^{172}$ See supra note 152 . Not all checks exercised by one branch against another should be considered punishments-consider, for example, the presidential veto or the judicial power to hold statutes unconstitutional-but all punishments administered by one branch to another should be considered checks. What the Nixon resignation makes 
well, the Court might conclude that the creation of the fresh remedy of civil damages for a President's abuse of power is neither necessary nor proper and is consequently not encompassed within the judicial power of the United States. ${ }^{173}$ There are, however, important reasons for reaching the opposite conclusion with respect to his aides. Before considering those reasons, it is appropriate to pause and consider the implications of the argument just presented.

\section{B. The Sometimes-Forgotten Congressional Role}

In its modified version, the rule banning the creation of new remedies explains the presidential immunity decision and a large body of additional precedent as well, but fails to answer the nagging question of why the courts should bother to issue orders to the President when they have no way of enforcing the orders against him.

The real answer may be that in the system of checks and balances, the courts are equal to the other branches. Thus in the end, it is the degree of political power that can be mustered that matters. ${ }^{174}$ If public

plain is that no systemic weakness requires his further punishment; the existing political checks proved adequate to halt his wrongdoing. The individual's claim to relief when harmed by official misconduct presents a different question. For the treatment of that issue under this theory, see infra text accompanying notes 208-19.

173 Under the theory propounded in the text, the conclusion that a civil damage remedy is neither necessary nor proper might change should there come a time when the full weight of the federal legislative power is insufficient to restrain further presidential misconduct. At that point, the federal courts might see the need to step in with fresh remedies. The issue may be of purely theoretical interest, because if Congress really could not control the President, judicial intervention might have little practical effect. $C f$. infra note 175 (similar point on restraining congressional misconduct).

The general thrust of the first sentence of this footnote-that the meaning of the Constitution's structural provisions as well as of its substantive clauses may change with time-is somewhat different from the approach taken in the historical discussion a few pages back, although it is in keeping with the ideas espoused by the scholars quoted supra note 68. Arguments have indeed been made that the "correct" interpretation of various structural constitutional guarantees has changed over time. See, e.g., First Agricultural Nat'l Bank v. State Tax Comm'n, 392 U.S. 339, 349-59 (1968) (Marshall, J., dissenting) (tax immunity of nationally chartered banks); Munzer \& Nickel, supra note 69, at 1048-50 (treaty-making power).

${ }^{174}$ After reading these words in an earlier version of this Article, Professor Robert Cover penned the following observation:

It is an ancient idea that the judge/magistrate has as one of his primary functions the job of controlling the "haughty, upraised arm of the mighty." That law directed at controlling the mighty may fail goes without saying. It also goes without saying that control over the weak and humble does not require law.

Thus, the pronouncements made on the limits on judicial power in this section of the essay should not be read as endorsements of the inequities inherent in the system. In addition, nothing said here about the judicial role regarding the system of checks and balances should be thought to apply ipso facto to the judicial role in the protection of 
opinion favors the Supreme Court as the most legitimate decisionmaking body, then another branch of government will ignore a judicial order at its peril. But had the New Deal Supreme Court, for example, tried to issue an order running directly against President Roosevelt, his likely defiance might severely have tested that legitimacy. ${ }^{175}$ The risk involved in issuing orders against the President does not mean that these orders should not issue. It means only that in seeking enforcement of the orders, the courts must take their chances in the political arena, just like everybody else. ${ }^{176}$

individual rights against government excess.

${ }^{173}$ By the same reasoning, judicial review of presidential impeachment proceedings, which several scholars have suggested is permissible, see, e.g., R. BERGER, supra note 94, at 103-21; Karst \& Horowitz, supra note 55, at $51 \mathrm{n.25}$, might have little practical effect. Given Congress's historical reluctance to use the machinery of impeachment, the degree of public disapproval necessary before Congress would impeach and convict a President of the United States can scarcely be imagined. See supra text accompanying notes 1-3. It is therefore remarkable that anyone would assume that the kind of steamroller that could flatten a Chief Executive would pause because a federal court asserted the power to intervene. $C f$. J. CHOPER, supra note 59, at 125 (quoting Jerome Frank) ("when public opinion reaches the proportions of a tidal wave, no merely intellectual appeal can stop it"). A President with the political strength to shield himself with a court order probably would have been strong enough to resist impeachment in the first place. One might even argue that only a politically strong President could convince a federal court that his challenge to congressional impeachment proceedings presents a justiciable question. See supra text accompanying notes 162-65 (judges may hesitate to issue orders not expected to have any effect). Similarly, a politically powerful Chief Executive might have been able to convince the Supreme Court that the issues involved in United States $v$. Nixon were not justiciable.

178 Although laws, very nearly all laws, are readily accorded general acquiescence, and are easily effective, there are times when law does not gain general consent merely by virtue of having been authoritatively pronounced, and lacking such consent it cannot be effective. . . .

When people in the millions or even hundreds of thousands are opposed-intensely, consistently, and on principle-to a law bearing directly on their conduct of ordinary affairs; effective enforcement is possible, if at all, only through military occupation. . . .

The crucial point is that we engage in a contest of wills. . . [Q]uite literally ... no one is under any legal obligation to carry out a rule of constitutional law announced by the Supreme Court until someone else has conducted a successful litigation and obtained a decree directing him to do so. Any rule of constitutional law not put into effect voluntarily by officials and other persons who acquiesce in it, or not taken up by legislation and made more effective by administrative or noncoercive means-any such rule is not in our system an effective rule of law. If there is widespread nonobservance, the resources neither of private litigating initiative nor of the judicial process as such are equal to making it effective. The Court thus interacts with other institutions, with whom it is engaged in an endlessly renewed educational conversation. It is a conversation that takes place when statutes are construed, when jurisdiction is defined and perhaps declined, when the lower federal courts are addressed by the Supreme Court as their "administrative head," and also when large "consti- 
One reason that this may rankle is that if the Court really must enter the political arena to enforce its orders-and the Court's lack of either purse or sword should make plain that it must ${ }^{177}$-then the available punishments for presidential abuse of power seem suddenly inadequate. This appearance of inadequacy stems rather from the unfortunate fact that the federal government has come to operate somewhat differently from the government that the Framers envisaged. This evolution does not mean that the scheme of checks and balances needs a drastic overhaul-that presidential liability in civil damages or some form of legislative veto is now necessary and proper-but rather that Congress should begin again to play the role that the Constitution sets for it in controlling presidential action.

The system of separated and balanced powers, more than it does anything else, makes a statement about process. The Framers foresaw a dynamic and continuing struggle for superiority, ${ }^{178}$ particularly between the two political branches of the federal government. ${ }^{179}$ This struggle would not necessarily revolve around a series of issue-by-issue confrontations; rather, each branch would act in many areas at the same time, using the full panoply of its powers to push forward in some fields while backing off in others. ${ }^{180}$ In recent years (or perhaps

tutional issues" are decided. And it is a conversation, not a monologue.

A. Bickel, Morality, supra note 164, at 107-11. Thus, in the "political arena," things do not happen because they are "supposed to," but because someone does them. The orders of a court are not obeyed merely because they are "supposed to" be, but because someone decides to enforce them or to obey them.

177 See The Federalist No. 78 (A. Hamilton).

178 See The Federalist No. 51 (J. Madison); G. Wood, supra note 71, at 44653 , 606-15; cf. B. BAILYN, supra note 71, at 70-77 (1967) (colonial conception of British balance of powers). As former Attorney General Levi has explained:

The separation of powers doctrine . . . is a political doctrine. It is based ... on the idea that government institutions given separate functions, organizations and powers will operate with different modes of reasoning. Each mode is important to the process of law formation and to the generation of popular consent to the law.

Levi, Some Aspects of Separation of Powers, 76 Colum. L. REv. 371, 390 (1976) (citing Buchanan, So Reason Can Rule; The Constitution Revisited, in Great Books of THE WESTERN WORLD LibRaRY 435 (1975)).

This idea of the political nature of the system of checks and balances lies behind Professor Choper's Separation Proposal. See J. CHopeR, supra note 59, at 265-70.

${ }_{179}$ The Framers thought the struggle would occur mainly between Congress and the President not because they believed that the Supreme Court would not strive to compete with the other branches, but rather because they hoped that the Court, being purely reactive, was less dangerous than the other branches. See The FederalisT No. 78 (A. Hamilton); see also A. BICKEL, supra note 69, at 199-243.

180 See generally G. WOOD, supra note 71, at 547-62, 574-80; Levi, supra note 178 , at 373-80. A general sense that the Framers viewed the system of checks and balances as dynamic rather than static emerges from a study of such writings as Madison's The FEDERAlist Nos. 47, 48, and 51, and from statements at the time of 
recent decades) the President has been doing most of the pushing forward and Congress most of the backing off. ${ }^{181}$ The only important exception came during President's Nixon's second term, when a dramatically weakened President sometimes backed off too far. ${ }^{182}$ Aside from that episode, although it still plays an enormous role in structuring the operations of government, Congress has been relatively docile. The legislators rarely act to rein in executive misuse of power or to force their policy choices on a reluctant President. If the presidency sometimes seems out of control-if the executive branch seems to have arrogated considerable power at the expense of Congress-the fault may lie primarily with politicians in Congress who lack the will and the courage to rein the executive branch in. While there are obviously other, more complex reasons, ${ }^{183}$ it can hardly be said that Congress lacks the power.

drafting and ratification suggesting that remedies such as impeachment were intended to address patterns of abuse, see infra note 203.

181 "The Youngstown decision assuredly did not stop the flow of power from Congress to the President. Only Congress can do that and in recent decades it has seldom bothered to try." Karst \& Horowitz, supra note 55, at 66. Some commentators think otherwise. See, e.g., S. Huntington, American Politics: The Promise of DisHARMONY 203-10 (1981) (arguing that Congress increased its power at the expense of the presidency during the 1960's and 1970's); Levi, supra note 178, at 382 (suggesting that problem of presidential arrogation of power can be traced to the time of Jefferson).

182 Perhaps, in the wake of the Watergate scandals and the Vietnam War, Congress began to reassert itself in many of the ways that the Framers intended, exercising authority that had lain dormant for many decades. See Zeidenstein, The Reassertion of Congressional Power: New Curbs on the President, 93 PoL. Scr. Q. 393 (1978). The broad personal popularity of President Reagan may have slowed this trend-if it is a trend-and might even have set it back a little, but as the President's standing in opinion polls has dropped, congressional backbone has stiffened. See infra note 185.

183 To take just one example, Professor Black has argued persuasively that perhaps the President really has become too strong, now that the veto has changed from a device for protecting the presidency against encroachment to a means for enforcing political decisions. Black, Some Thoughts on the Veto, LAw \& ConTEMP. ProBs., Spring 1976, at 87. Black responds to critics of Congress this way:

Every candidate for the job of editorial-writer should be required to take an examination with one question: "If 65 per cent in each House of Congress favor and pass a comprehensive bill on energy, and the President very much does not like it, what happens?" Because then we might hear (and above all, for the sake of mercy, read) less criticism of Congress for its "failure to act," and so on, ad nauseam. If you have a 65 per cent majority in each House strong for a consumer bill, say, and the President is dead set against it, then that consumer bill will not become law.

Id. at 94-95. Nor will it do, Black contends, to argue that Congress has a responsibility to pass what legislation it thinks best and then, in essence, to dare the President to veto it.

[T]he practical task of the leadership of the House of Representatives and the Senate . . . is not to draft and pass a bill that seems good to strong working majorities in the House and Senate. It is to produce a bill, acceptable to those majorities, so reluctantly swallowed by those majorities, that may get by a veto. 
The Framers of the Constitution probably considered the Congress the most powerful branch of the new government they were creating. As the Supreme Court has noted, the history of the drafting and ratification is "replete with expressions of fear that the Legislative Branch of the National Government will aggrandize itself at the expense of the other two branches."184

In the main, Congress legislates, and its legislative powers are enormous. Congress can slash appropriations for programs the President favors and ram down his throat appropriations for programs he would prefer to dissolve. ${ }^{185}$ In large measure, Congress may channel the discretion of the executive branch and its agencies, setting policy preferences and creating or rebutting presumptions. In truth, there is little that the President can do for any length of time if Congress as a body seeks to stop hi;m. Congress occasionally does try, but as a general rule, it now mostly reacts to executive initiatives rather than pursuing any of its own. ${ }^{186}$

Id. at 95. Nevertheless, Black concludes, much as this essay does, that the solution is for Congress to fashion its other constitutional powers into effective weapons with which to force the President to compromise. See id. at 99-101.

If the President really does hold too much power, moreover, there must be contributing factors other than a failure of congressional will. American society has changed drastically over the past two centuries. The broadcast media focus attention on the President as an individual and Americans come to know their President in a way that they can never know leading members of Congress. Problems often seem to demand rapid, even immediate solutions, and Congress, a deliberative body, cannot work that way. The President is therefore left to fulfill the popular demand for decisive action. In addition, the executive branch, because it is motivated by the personality and values of a single individual, may be able to adapt to changing circumstances more easily than Congress. Improved party discipline, enforced by a "leadership committee" of the sort used during Reconstruction, might be one way that the legislative branch could better cope with the need for rapid solutions. There is, however, no apparent prospect that the leadership will garner so much power.

While these observations provide a background against which congressional inaction may be evaluated, they do not, without more, justify the shift of authority from the legislative to the executive branch. Altering the course is still a congressional responsibility.

184 Buckley v. Valeo, 424 U.S. 1, 129 (1976) (per curiam). See also Watson, Congress Steps Out: A Look at Congressional Control of the Executive, 63 CAlIF. L. REv. 983, 1030-49 (1975).

185 Recent examples of those processes at work include President Reagan's partial defeats on the issues of funding for covert operations in Nicaragua and for the Legal Services Corporation. For the Framers, the congressional power over the purse was one of the most important checks on executive authority. See THE FEDERALIST No. 48, at 345 (J. Madison) (B. Wright ed. 1961) ("the legislative department alone has access to the pockets of the people" which creates "a dependence" on Congress in the other branches).

${ }^{180}$ The Supreme Court's recent decision in Immigration \& Naturalization Serv. v. Chadha, 103 S. Ct. 2764 (1983), holding unconstitutional most forms of the legislative veto, may have the long-term effect of forcing Congress to react less and initiate more. See, e.g., N.Y. Times, June 24, 1983, at A1, col. 5 (predicting this change); id., July 5, 
This congressional passivity might shock many of the Framers of the Constitution, who assumed that Congress would make the laws. ${ }^{187}$ The past two centuries, however, have brought about additional, perhaps more startling changes in the relationship between the Congress and the President. One such change is the virtual atrophy of the power of the Senate to advise and consent on appointments. ${ }^{188}$ Confirmation of most presidential appointees has become a mere formality. With a handful of exceptions, the modern congressional approach has been to judge individual nominees on what are sometimes called "the merits," which generally refers to track record and political skeletons. The Senate usually ignores the possible use of its confirmation power to force presidential concessions on other issues. ${ }^{189}$ Judging appointees purely on their merits seems a wonderfully liberal idea, but in practice-especially when combined with the widely-accepted myth that the President "deserves" to install "his own team" in the executive branch-it eliminates a major means for checking the President. The Framers apparently expected that Senate confirmation of his nominations would be a carrot with which the Senate could tempt the President to give ground in other areas. ${ }^{180}$ If the President misbehaved on

1983, at A19, col. 1 (suggesting some changes). See generally Kaiser, Congressional Action to Overturn Agency Rules: Alternatives to the "Legislative Veto," 32 AD. L. REv. 667 (1980).

${ }_{187}$ But see infra note 199.

188 U.S. CoNST. art. II, § 2.

180 The Senate has tended to scrutinize judicial appointments with a bit more care, and for a reason that should be plain: judges, who remain in office long after the Administration has left, are not part of the President's team. To illustrate this principle, one need only recall the results of President Hoover's nomination of Judge Parker to the United States Supreme Court and of President Nixon's nominations of Judge Carswell and Judge Haynsworth to that tribunal. The point is not that the Senate was "right" or "wrong" in rejecting these nominations; the point rather is that a different standard would probably have been applied had the three been nominated for posts in the executive branch.

180 Writing in The Federalist, Hamilton contended that the Senate would consent to nominations on the basis of the merits of the candidates involved. THE FEDERALIST No. 76, at 482-84 (A. Hamilton) (B. Wright ed. 1961). He conceded, nevertheless, that this contention was counterintuitive, that the exercise of the appointment power would ordinarily be expected to serve as an occasion for negotiation and coalition-building, for giving on some issues in order to take on others. Id. In the course of the debates over the drafting and ratification of the Constitution, any number of delegates echoed the latter view. See, e.g., 2 ReCoRDS, supra note 75, at 522-23 (J. Wilson) (Senate will treat President as "Minion"); 3 id. at 357 (R. Sherman) (Senate's power "would tend to secure the liberties of the people"); 4 DEBATES, supra note 83 at 116-18 (S. Spencer) (President will take only action that is "convenient" for leaders of Senate; 2 DocUMENTARY HiSTORY, supra note 76, at 508 (J. Smilie) (as long as Senate has power of confirmation, President is "merely a tool to the Senate"). In practice, the Congress has adopted a number of plans-some more constitutional than others-to limit the President's appointment power without seeming to reject qualified nominees. See E. CoRwin, supra note 47, at 73-79. A polite form of horse-trading is the venerable "sen- 
issue A, then his candidate for position B would not, no matter how highly qualified, be confirmed. If the President yielded on issue $\mathrm{C}$, then his less-than-qualified crony would be confirmed for position $D$. At times, this kind of political horse-trading still goes on, ${ }^{191}$ but the general expectation that Senators should and will focus on the merits forces the deals behind the scenes, because horse-trading is considered somehow disreputable rather than a part of the constitutional process. This is unfortunate. One need only consider the vast range of positions for which Senate confirmation is required to realize the potential for congressional limitation of the executive inherent in the conformation power. ${ }^{182}$

Just as the confirmation power has, in recent decades, lost much of its force as a check, so have several types of congressional action that could be used to punish executive abuses of authority or to force changes in executive policy. ${ }^{103}$ The relatively rare use of the impeachment machinery against presidents might show that the nation has had a surfeit of good and kind and wise executives, but it might also provide evidence that Congress feels constrained by its own power rather than emboldened by it. So the massive potential of Congress's many powers lies untapped, the dynamic nature of the system of checks and balances is ignored, and Congress continues to seek ad hoc means for controlling presidential action on particular issues.

In keeping with this flawed approach has been the consistent congressional reliance on the "legislative veto." Through this device, Congress has sought to delegate broad authority to the executive branch

atorial courtesy," through which a Senator may hold up nominations for federal officers within his own state. See id. at 73-74.

101 Even judicial appointments are not immune to horsetrading. For example, the nomination of Thurgood Marshall to the United States Court of Appeals was supposedly held hostage by Senator Eastland, chairman of the Senate Judiciary Committee, until President Kennedy agreed to nominate Harold Cox to a vacancy on the District Court in Mississippi. See Caldwell, Harold Cox: Still Racist After All These Years, Am. Law., July 1979, at 29.

192 Although there are practical limitations on the exercise of the power, the Constitution permits Congress to require Senate confirmation of virtually any employee of the United States. U.S. CoNST. art. II, § 2.

193 In addition to the more obvious powers already discussed-abolition of particular departments, withholding of appropriations-Congress also possesses a rather substantial discretion to conduct investigations. This discretion has been held to be part of the legislative power. See, e.g., Sinclair v. United States, 279 U.S. 263, $291-92$ (1929); McGrain v. Daugherty, 273 U.S. 135 (1927); see also Barenblatt v. United States, 360 U.S. 109 (1959). The result in Barenblatt is often excoriated, but the majority's language does purport to construe the investigative power narrowly, limiting it to areas in which Congress "may potentially legislate or appropriate." Id. at 111. A somewhat dated, but still useful, discussion of various means that Congress can use to control the President is J. Harris, Congressional Control of Administration (1964). 
while retaining a measure of control over the exercise of that authority. In mid-1983, however, the Supreme Court ruled in Immigration and Naturalization Service v. Chadha ${ }^{\mathbf{1 8 4}}$ that most forms of the legislative veto are unconstitutional. Six members of the Court agreed that because the veto did not involve the exercise of one of Congress's implied or enumerated powers, its use violated the principles of separation of powers. ${ }^{195}$ The Court rejected arguments that the legislative veto was essential to allow Congress to delegate authority without giving the executive branch completely free rein. Not everything that is arguably "necessary" or "efficient," the Court reasoned, is constitutional. ${ }^{196}$ Thus, the Court's conclusion in Chadha underscores an important point made earlier: that those who advocate the creation of new checks may ultimately be subverting the system in the guise of saving it. ${ }^{197}$

Critics of the Chadha decision quickly contended that in a modern activist state, Congress "needs" the weapon of legislative veto, or much power that should be delegated will not be. Congress will not delegate the power if doing so means losing control over the power's exercise. ${ }^{198}$ That argument, in spite of some surface appeal, illustrates the conceptual difficulty shared by the legislative veto and the notion that the President should be liable in civil damages for his official misconduct. Both ideas are motivated by the view that institutional remedies are necessary to respond to specific instances of abuse of authority. Both ideas treat the relationships among the branches as part of a static, stimulus-response type system, rather than a dynamic one in which the working balance of power is constantly shifting. Both ideas, moreover, seek to create fresh weapons in the struggle to control the President. In rejecting both proposals the Supreme Court has evinced a clear preference for the use of the considerable powers that the Constitution, on its

104103 S. Ct. 2764, 2788 (1983).

${ }^{205}$ Although Justice Powell wrote a separate concurring opinion and Justices White and Rehnquist both authored dissents, only Justice White expressly disagreed with the majority on the merits.

${ }^{188}$ Chadha, $103 \mathrm{~S}$. Ct. at 2788. The argument that efficiency can support constitutionality was frequently made prior to the Court's decision by proponents of the legislative veto. See, e.g., Miller \& Knapp, The Congressional Veto: Preserving the Constitutional Framework, 52 IND. L.J. 367 (1977); Stewart, Constitutionality of the Legislative Veto, 13 HARV. J. ON LEgIS. 593 (1976).

197 See supra text accompanying notes 104-05.

${ }^{198}$ In Chadha, the majority apparently disagreed with this contention, because in ruling on standing to sue, the Justices decided that Congress would have delegated the power in question ( $\$ 244$ of the Immigration and Naturalization Act, 8 U.S.C. § 1254 (1976), whether or not the legislative veto was available. $103 \mathrm{~S}$. Ct. at 2786. As Justice Rehnquist noted in dissent, the Court's conclusion is somewhat bizarre because Congress was delegating a power it had previously exercised itself and probably did so only with the understanding that it would retain a check on the power's exercise. 
face, grants to Congress. The checks expressly authorized should be adequate to rein in an abusive President. ${ }^{198}$ If it is dissatisfied with the standard for benzene exposure promulgated by the Occupational Safety and Health Administration, Congress need not resort to a legislative veto to force a change. Congress could, for example, refuse to vote an appropriation that the President desires or postpone the confirmation of one of the President's nominees. Members of Congress should not hesitate to hold one program hostage in order to force changes in another. ${ }^{200}$ If public pressure makes this strategy impossible, that simply means that in a particular political struggle, the President has won. That a system does not in the face of opposing public opinion lead invariably to victory, hardly means that the system is evil or even weak.

Naturally, if Congress is going to use the full measure of its authority to force concessions in one area in return, perhaps, for retreating itself in another, the leadership will have to pay careful attention to the system of checks and balances. The decline of party discipline may mean that the leadership will have difficulty in exercising control, ${ }^{201}$ but with the demise of the legislative veto, enlightened self-interest may move the Members into more consistent coalitions. No other course is likely to lead to restoration of the balance of power, for the Supreme Court's opinions in Chadha and Nixon v. Fitzgerald stand as obvious calls to put politics back into the governing process. ${ }^{202}$ The system of checks and balances is, after all, a political one, and its structure suggests that the Framers cared more about making sure that no one

199 The term "abusive President" is used advisedly. Congress might be concerned with two types of abuses: those involving wrongdoing in office, for which punishment might be appropriate, and those involving the making of policy, for which pressure rather than punishment would be appropriate. In designing the system of checks and balances, the Framers were more concerned with the former than with the latter. They were worried about creating a tyrant who would abuse his powers. They did not anticipate that the President would (through the growth of the executive agencies) also outstrip the Congress in the race to make policy. For the Framers, Congress alone was the lawmaking body, and it was the President merely who would react to the legislature's initiatives. The alignment anticipated by the Framers has shifted nearly 180 degrees. The reasons for the shift are probably complex, see supra note 183, but the solutions must involve something other than attempts by Congress to find new ways to react to policies proposed by someone else. The legislative veto was constitutionally doomed in part because it tried to do precisely that. Instead, in keeping with the way the system of government was designed to work, Congress should be searching for ways to regain preeminence (or at least equality) in the proposal as well as in the disposal of policy initiatives.

200 See supra text accompanying notes 189-92.

201 But see supra note 183.

202 One of the most unfortunate aspects of the reform-minded 1960's and 1970's was the way that the word "politics" became more or less synonymous with "bad government." But the Constitution is a political document, not just a legal one, and not all decisions on wise policy need be made by "experts." 
branch held total sway than they did about assuring the "best" decision on every issue that might arise. In developing the structure of government, the Framers sought to give each branch the powers necessary to respond to patterns of abuse. ${ }^{203}$

Thus, probably no one thought in 1787 that a President would be impeached or defeated for reelection merely because he fired a single civil servant unjustly or ordered a single illegal break-in. ${ }^{204}$ A President might be impeached or defeated for either of those misdeeds, but the issue would be entirely political, in the literal sense of that word: the system would respond if public opinion considered the abuse sufficiently heinous. On the other hand, should a President order a series of illegal break-ins, sabotage political opponents, conspire to obstruct justice, and order secret military operations abroad, the Framers would undoubtedly have felt that a pattern had been established, that here was a tyrannical Chief Executive who had to go, whether by impeachment or by resignation. ${ }^{205}$

The same would be true of an injunction or subpoena. Yes, a court

${ }^{203}$ Both the words of the document and its history make clear that the Framers contemplated impeachment of a President who committed a felony, but aside from felonies, the evidence does not suggest that the President was to be punished for discrete wrongs. This limitation should be plain from the structure of the government the Constitution creates. The machinery available for presidential punishment-impeachment, legislation, failure of reelection-is so unwieldy that it cannot easily be brought to bear on a President whose acts are, in the view of the political actors in the system, relatively minor. Some of the remarks made during the debates also suggest a concern for patterns of abuse rather than for wrongs done to particular individuals. During the Philadelphia Convention, Madison argued that without the remedy of impeachment, the Chief Executive "might pervert his administration into a scheme of peculation or oppression." 2 ReCORDS, supra note 75, at 65-66. Randolph's fears that the President would grow too powerful in time of war absent the impeachment remedy, are difficult to understand in any other way. Id. at 67. And Franklin's half-joking reference to assassination, id. at 65, was not likely aimed at a President whose "misconduct" comprised a single wrong done to one individual.

The historical evidence is hardly conclusive on the point, but when joined with the structure of the system of checks and balances, the evidence does suggest rather strongly that the Framers were not worried about such issues as whether a single civil servant would lose his position unjustly. Perhaps the political and electoral checks on presidential misconduct are most effective when dealing with patterns of abuse but likely to fail when confronting individual claims of hardship that must, in the larger scheme, be considered de minimis. See infra note 209. Fortunately, the theory developed in text has the happy byproduct of permitting remedies for many individual claims. See infra text accompanying notes 208-19.

${ }^{204}$ The articles of impeachment adopted by the House Judiciary Committee shortly before President Nixon resigned did not include either of these charges. As the text makes clear, however, the mere fact that Congress chooses not to impeach the President for a particular abuse of authority does not mean that he will go unpunished. Lesser sanctions are often available.

${ }^{205}$ In fact, a strong argument can be made that the Nixon Administration ultimately became precisely the "scheme of peculation or oppression" that Madison insisted would render the Chief Executive impeachable. See supra note 203. 
may issue one, but if the President chooses not to obey, then it is up to the political process to decide whether he ought to be punished for his act of defiance. The political process includes the Congress, which will act if a majority of its members choose to do so, and the public, which may act if a majority of its members choose to do so. ${ }^{208}$ If the political process does not force the President to obey a court order, then the President will get away with disobeying it. The conclusion that the enforcement of judicial orders must be left to the political process is not likely to please people trained as lawyers, because lawyers seek rules and standards, and if enforcement of judicial orders is left to the political process, then there really are none. ${ }^{207}$ Lawyers, however, sometimes forget that the Constitution is not merely a legal document; it is also a political one. It describes more than a legal system; it describes a system of government. Not all the decisions made in a system of government are legal decisions. Many of these decisions are political ones, made not by the lawyers in the system but by politicians and voters. Among the decisions the Constitution vests in the political system is the decision whether to punish the President of the United States.

\section{But What About the Little Guy?}

If punishing the President is up to the political system and if the Framers were interested only in the big picture, then isn't civil damages liability an appropriate (which is to say, necessary and proper) means for granting relief to the little guy who has been wronged?

The answer is "no," although as will be seen, the "no" is a qualified one. The system of checks and balances, the preservation of which should be of preeminent concern, is a political system, and the struggle for supremacy among the three branches is similarly a political one. Supplying relief for the little guy-applying the maxim $u b i j u s$, $i b i$ remedium-is not the purpose of the system. ${ }^{208}$ That is not because the system is evil, but because trying to provide the best means for relief in

${ }^{208}$ The voters in turn may be influenced by the enormous power of the modern broadcast media, whose role in the function of the American political system has been only inadequately explored.

${ }^{203}$ For all that it may bother lawyers, the realization that the system of checks and balances is essentially standardless would neither surprise nor disappoint a political scientist. Cf. Levinson; Judicial Review and the Problem of the Comprehensible Constitution (Book Review), 59 TEX. L. REv. 395, 401 n.31 (1981) (suggesting distinctions between views taken by lawyers and those taken by political scientists on same institutions).

${ }^{208}$ To say that relief for the wronged little guy is not the purpose of the system is not to say it does not exist within the system. Fitzgerald himself, the plaintiff in the presidential immunity case, was reinstated with backpay, in addition to being permitted to pursue damages against presidential assistants. 
every case could, if it involves the creation of new remedies, raise the same intractable problem discussed in the last few sections: The system of checks and balances exists to eliminate the possibility of domination by a single branch of government. The system was not designed to vindicate each individual's every assertion of right. Any attempt to modify the system to provide additional checks and balances carries the risk of undermining the entire system. If one branch can "discover" or "impose" a fresh remedy (especially for misconduct that must, in the grander scheme, be considered de minimis) ${ }^{209}$ then that branch has a fresh weapon in its continuing struggle with the other two branches. In the absence of strict necessity, the constitutional scheme will not tolerate the creation of these new remedies. "Necessity," moreover, must refer to keeping the power in balance, and not to righting every wrong.

Improper presidential acts that do not provoke Congress into using one of its big sticks-impeachment, say, or a rebellion on appropriations-may yet be punished. If the President has political enemies carefully cataloguing his misconduct - and most Presidents do-then all his acts that are even arguably wrong will be added to that list. If the list grows long, the President's misdeeds may come back to haunt him as his opponents recite them from the pulpits of the press and the broadcast media. Perhaps more important, the petitioners can be heard by Congress if that body shows the spine and spunk to hear them. The President would not necessarily be impeached and convicted as a result, but even now, individual members of the Senate and the more powerful members of the House are frequently able to take individual grievances to the Administration. ${ }^{210}$ Of course, the administration may turn a deaf

${ }^{209}$ Certainly the wrongs charged in Nixon $v$. Fitzgerald were great and heinous, but that is not the question. The question is whether, if necessity is a criterion for the validity of new remedies, the necessity required should be based on the needs of a small group of individuals or on the needs of the system. The thesis expounded in this essay is that the only necessity justifying the creation of a fresh remedy is a fundamental breakdown in the system of checks and balances, a reason to believe that the system is not functioning as the constitutional structure requires. A failure to punish the President for a particular, discrete wrong does not amount to a breakdown of this sort. Although one might argue that a failure to rectify a wrong done to even one citizen is a breakdown that the system cannot tolerate (a proposition that is not easy to sustain, $c f$. infra note 215), the argument cannot fairly be made in the case of a suit seeking damages for injury resulting from presidential misconduct. The President cannot act alone, and someone will always be available as a proper defendant. See infra text accompanying notes 216-17.

210 This description of the process of seeking a remedy may bring back memories of old-style "boss" and "machine" politics, and the days when a citizen with a grievance against the government went to see the local ward leader. The image may be distasteful, but one should bear in mind that the idea of politicians acting out of squeaky clean idealism is of relatively recent vintage. An important part of political power, moreover, is the willingness to act to assist real individual people rather than 
ear, but if it does so too often, then a Congress that is fulfilling its role in the system of checks and balances should slow legislation, appointments, or treaties the President has promoted, until the administration becomes more cooperative. In this manner executive power can be controlled even if Congress takes no formal measures.

Very well: in rare cases some sort of institutional response may be forthcoming. But it will not be forthcoming in all cases, and perhaps not in most. A wronged individual may bring his complaint to Congress and yet receive no satisfaction. His Representative might ignore him, the Judiciary Committee might make no report, the House might vote not to impeach, the Senate, not to convict. None of that would mean, however, that the system was not working. It is a little like something Ann Landers once wrote of prayer: When someone prays but does not get what he wants, it does not mean that the prayer has gone unanswered. It means only that the answer is "No."

The political system would be called upon to answer the question whether the wrong done to a single individual by the President while handling the myriad responsibilities of his office outweighs everything else he might have done in a competent, even a brilliant, manner. The answer often will not be easy. If Congress refuses to act, then it has struck the balance against the petitioner and in favor of the status quo. ${ }^{211}$ If the President's abuses grow, however, his partisans in Con-

acting on behalf of some amorphous concept of "the masses."

This argument does not mean that the Constitution was in some sense "designed" to function in a system relying on political favors and debts. In their public rhetoric, many of the Framers professed the ideological conviction that political parties are anathema to the republican ideal. Arguably, the Constitution was drafted in part to limit the influence of parties. See R. Hofstadter, The IDEA OF a PARTY System 173 (1969). On the other hand, whether or not accepted in theory, political parties certainly existed and flourished before 1787. See generally J. MaIn, Polrtical Parties BEFORE THE CONSTITUTION (1973) (statistical analysis of voting patterns in state legislatures). Many preconstitutional party leaders represented their states at the Philadelphia Convention. See id. at 409-53 (names of party leaders). These party leaders presumably did not go to Philadelphia to reduce their own influence.

As voters have become more sophisticated and party identification less important, the power and importance of political parties have declined. See S. Huntington, supra note 181, at 205-10. That decline does not mean, however, that the ability of a single politician to seek relief for a constituent, or of a number of politicians to form temporary coalition on behalf of many constituents, has changed.

211 Congress may fail to act for any number of reasons, including mere partisanship. See Berger, The President, Congress, and the Courts, 83 Yale L.J. 1111, 113334 (1974). Berger made this point as part of an argument that punishment of the President should not be left to Congress, essentially because Congress cannot be trusted. Whether Berger is right depends, of course, on what Congress is being "trusted" to do. If the system is a political one-if it is standardless-then Berger's argument loses its force. Congress is after all a political body and, under this Article's view of the system, choosing whether to punish the President is a political act. 
gress might abandon him. Even a popular President may be toppled by the mass defection of supporters. This danger will lurk in the shadowy recesses of the President's mind, forcing him to glance over his shoulder as he embarks on a course he knows to be wrongful. The further down the road he goes, the larger the danger will loom. At some point, fear should stop him. As Elbridge Gerry remarked during the drafting of the Constitution, "A good magistrate will not fear [impeachments]. A bad one ought to be kept in fear of them."212 Of course the threat of catastrophe may not stop the President. It apparently did not stop Richard Nixon. But that is why the threat is capable of execution. If the fear of impeachment is not sufficient, then its reality should bring even the most abusive Presidency to a close.

The end of a Presidency may bring but little relief to the individual who believes himself wronged by the President, and seeks damages from him. Yet under the rule established in Nixon $v$. Fitzgerald, the President need not make the individual whole. Does this rule mean that there are indeed some rights for whose violation the law affords no remedy ${ }^{213}$ This question must be rephrased before it can be answered. Proponents of civil damages liability have consistently asserted that the number of "serious" lawsuits the President would have to face is small. ${ }^{214}$ This assertion necessarily implies, the litigiousness of our society being what it is (ubi jus, ibi lawsuit), that the number of individuals with serious grievances would also be small. So the real question is whether in a handful of cases, there will be violations of right for which there will be no remedy.

2122 RECORDS, supra note 75, at 66.

213 Blackstone's traditional formulation, echoed by Chief Justice Marshall in Marbury v. Madison, 5 U.S. (1 Granch) 137, 163 (1803) held that a "right" without a "remedy" is not worthy of the same. As will shortly be seen, a proper understanding of Nixon $v$. Fitzgerald does not require disputing these venerable precedents.

214 Professor Schuck's work in the field suggests that this assumption may be challenged on two grounds, accuracy and relevance. The challenge to the assumption's accuracy accepts the contention that only a handful of lawsuits have been filed against Presidents and former Presidents based on their conduct while in office, but notes that had the Court reached the opposite result in Nixon $v$. Fitzgerald the decision might have been read a broad invitation to those with grievances to come forward and sue. After all, since the Court handed down its decision in Bivens v. Six Unknown Agents, 403 U.S. 388 (1971), the number of civil damages actions against federal officials has increased dramatically. See P. ScHuck, supra note 29, at 199-202. Whether these suits are meritorious is irrelevant; the important point is that they exist.

The challenge to the assumption's relevance disputes the contention that because an "objective" standard (what a reasonable person would have understood) is applied, and because the Justice Department will provide defense for those sued in their official capacity, frivolous actions will be dismissed on the pleadings at virtually no cost to the defendant. Professor Schuck suggests that the cost to the defendant can prove quite substantial, even if not in money. Id. at 114-62. 
A "yes" answer would not be difficult to defend, because the rules of any forum may be sufficiently strict to stifle some claims for relief. There is no reason to expect special treatment for victims of presidential wrongs. The right answer, however, is "no," for a reason that should be plain. An individual wronged by presidential order is not without a damages remedy; he will ultimately be made whole. $\mathrm{He}$ is only without the defendant of his choice. The President does not act alone. In this sense, he is analogous to the British monarch who, some delegates pointed out during the ratification debates, cannot carry out any act without the assistance of aides, who may be punished. ${ }^{215}$ If any individual is harmed by presidential decree, he may sue all the functionaries below the Chief Executive in the chain of command from order to act.

The lesser functionaries may be held liable because the Supreme Court has extended to them its common law implied cause of action. ${ }^{\mathbf{2 1 6}}$ The best rationale for their liability, however, is not the need for awarding damages to an injured party, but the need to provide adequate checks on official malfeasance. The existence of civil damages actions against presidential aides is a useful by-product of the decision in Harlow $v$. Fitzgerald, but the desirability of providing a remedy for the wronged individual is not a sufficient justification for the holding. Under the analysis presented in this essay, Harlow $v$. Fitzgerald was correctly decided only if this additional check is necessary to maintain the balance of powers.

The best argument for the necessity of this check is that although the Constitution establishes a framework for punishment and control of

218 This comparison to the British monarchy was used two ways. For James Iredell, speaking in the North Carolina ratification convention, the distinction between the Crown and the President was an argument in favor of ratification. The King was presumed to do no wrong, and his adviser would be punished in his stead. The President, "[if] he commits any misdemeanor in office, . . . is impeachable, removable from office, and incapacitated to hold any office of honor, trust, or profit. If he commits any crime, he is punishable by the laws of his country, and in capital cases may be deprived of his life." 4 DEBates, supra note 83, at 109. For-Gouverneur Morris, in the Philadelphia Convention, this same distinction was (until he changed his mind) an argument against the necessity for impeachment: "[The President] can do no criminal act without Coadjutors who may be punished. In case he should be re-elected, that will be sufficient proof of his innocence." 2 RECORDS, supra note 75, at 64.

${ }_{216}$ The Court held that the so-called "objective standard" applies to these cases. The application of this standard means that if the defendant can show that he acted as a reasonable person would have under the circumstances, the plaintiff will probably recover nothing. See supra note 140 and accompanying text. That result is a function of the standard of liability and has nothing to do with whether the plaintiff can seek to be made whole. A damages action for official misconduct is like any other damages action: when the defendant has an adequate defense, the plaintiff, injured or not, will recover nothing. 
an evil President, it does not do the same with respect to lower federal officials. ${ }^{217}$ Thus, civil damages liability for the lower officials does not constitute a fresh check in the same way that similar liability for the President would constitute one. The constitutional system of separated and balanced powers is designed to keep in check the President himself, not his aides. That same system is adequate for preserving a congressional role in the making of policy, which is why Chadha was rightly decided. Legislative vetoes and civil damages liability of the President would upset the delicately crafted system. With respect to the President's aides, however, there is no delicately crafted system to upset. ${ }^{218}$ Thus, civil damages liability for lower executive-branch functionaries is arguably necessary to preserve the balance of powers. Happily, the remedy has the advantage of making whole those who have been damaged by executive action. ${ }^{219}$

The issue, then, is not really whether a remedy exists, but only whether the President is to be among those against whom the remedy will run. Resolution of that issue has nothing to do with setting right a wrong and everything to do with the balance of powers. ${ }^{220}$

217 In particular (although this argument can be taken too far), the constitutional structure provides evidence that the Framers did not anticipate the massive growth in the power and responsibility of the executive branch. The Framers came to the Constitution from the experience of the Articles of Confederation, which created no executive branch. Although the desire to create a strong executive did much to motivate the call for a new Constitution, see generally G. Wood, supra note 71, at 393-429, it would be counterhistorical to assume that the executive branch as it exists today is the one that the Framers anticipated. This justification may not be the most effective one for the result in Harlow v. Fitzgerald, but it is the type of argument that must be made if the case is to be explained under the theory advanced in this essay. The alternative is the one advocated by the Chief Justice in his dissent in Harlow $v$. Fitzgerald to wit, that the case was wrongly decided. But it is far easier to show that presidential assistants are unlike the functionaries sued in the cases he cites, see supra note 117 , than to show that they are like the President.

218 Those who consider the original understanding may find significance in the apparent belief of some of the Framers that a civil damages action would lie against the President's aides. See, e.g., 4 Debates, supra note 83, at 46-48 (A. Maclaine) (discussing suit against inferior officer who abuses authority); 2 RECORDS, supra note 75, at 64 (G. Morris) (President's aides "may be punished," at least for criminal acts).

210 When no assistants are available as defendants, the President must have acted alone. The gist of Professor Freund's argument, quoted supra note 114, is that when the President acts alone, he may be susceptible to judicial process.

220 Presidential immunity might also help to balance powers in a slightly different sense, one suggested to me by Robert Cover. The tradition that a former President will not be held to account for his conduct in office may underlie another tradition, one that Americans take for granted. This is the tradition of smooth and nonviolent transfers of power from one administration to the next. In many other societies, where former heads of government are frequently tried and punished for their "abuses" of power, the premiers spend large parts of their terms searching for ways to cling to authority-or to protect themselves when they finally leave office. Their efforts may include compiling information on political opponents to purchase a safer retirement; the arrest or assassi- 


\section{Conclusion}

The journey has been a little long, but in the end, the outcome in the presidential immunity case turns out not to be so startling. ${ }^{221}$ The decision conforms to tradition and to intuition. Constitutional tradition holds that the courts declare what the law is, and nothing in the case prevents them from doing that. Intuition suggests that the President is not above the law, and nothing in the decision places him there. That leaves the question of who decides what should happen when the President chooses not to do what the courts decree. In a political system, that is a political question. If Nixon $v$. Fitzgerald makes a statement about constitutional law, the statement is probably that absent extraordinary necessity, it is for the political actors in the system-members of Congress and the voting public-to deal with presidential misconduct.

This theory reflects a view of the Constitution as a political as well as a legal document and a view of the federal government as the proper province not only of the courts but of the other branches as well. It would be all too easy to leave every issue arising under the Constitution to judicial resolution, but Nixon $v$. Fitzgerald is a subtle reminder that the courts cannot govern alone-and that the system's political actors should not want them to. In this sense, the presidential immunity decision may be viewed as a kind of call to action. If there is a prevailing view that the presidency is getting out of hand, then the time has come for the government's potentially most powerful branch to reassume supremacy. The power to make law includes the power to punish and rests mainly with the legislature. The legislature does not do its job unless it is willing to legislate, to reach decisions, to set policy. These are the tasks that a Congress that governs ought to be performing. Every day that it does less-that the voters do not force it to do more-it is acquiescing in a shift of power to the executive branch. Congressional weakness, because it threatens to upset the balance of power, results in calls for extra-constitutional remedies. Those extra-

nation of likely successors; the perversion of governmental apparatus for rapid pecuniary gain for a safer retirement; or even the suspension of democratic processes, making an orderly succession impossible. Americans are fond of saying that it can't happen here, but whenever something that might happen doesn't happen, there is a reason for its nonoccurrence.

${ }_{221}$ To say that the result is not startling is not to approve the reasoning process through which the majority reached it. One may appreciate the essence of a thing without liking all of its form. A reader may say of Nixon $v$. Fitzgerald much the same thing that Mikhail Botvinnik, then chess champion of the world, said of a game he contested with Bobby Fischer, then a teenaged prodigy. The game was complex and exciting and hopelessly flawed, leading the world champion to comment later on: "Too many mistakes?' the reader may justly ask. Yes, there were rather a lot!" B. FisCHER, MY SiXTY MEMORABle Games 253 (1969) (quoting Mikhail Botvinnik). 
constitutional remedies, however, might in turn destroy the balanced system they are meant to preserve.

The message of Nixon $v$. Fitzgerald appears to be that the Supreme Court will not in the absence of extraordinary necessity act to save Congress from its own weakness, to punish a President that the legislature is unable to control. It is up to the political actors to save themselves. If they do not, then the federal courts, sitting on the sidelines, might finally be forced to enter the game. By the time they do, however, it may be too late. If it is, then the other players will have only themselves to blame. 
HeinOnline -- 131 U. Pa. L. Rev. 1402 1982-1983 